\title{
Arbeidsmarktongelijkheid onder hbo'ers
}

Citation for published version (APA):

Belfi, B., Allen, J., Jacobs, B., \& van Oosterhout, K. (2018). Arbeidsmarktongelijkheid onder hbo'ers: Hoe individuele achtergrondkenmerken van hbo'ers samenhangen met arbeidsmarktsucces op de korte en middellange termijn. ROA. ROA Reports No. 009 https://doi.org/10.26481/umarep.2018009

Document status and date:

Published: 01/01/2018

DOI:

10.26481/umarep.2018009

Document Version:

Publisher's PDF, also known as Version of record

\section{Please check the document version of this publication:}

- A submitted manuscript is the version of the article upon submission and before peer-review. There can be important differences between the submitted version and the official published version of record.

People interested in the research are advised to contact the author for the final version of the publication, or visit the DOI to the publisher's website.

- The final author version and the galley proof are versions of the publication after peer review.

- The final published version features the final layout of the paper including the volume, issue and page numbers.

Link to publication

\footnotetext{
General rights rights.

- You may freely distribute the URL identifying the publication in the public portal. please follow below link for the End User Agreement:

www.umlib.nl/taverne-license

Take down policy

If you believe that this document breaches copyright please contact us at:

repository@maastrichtuniversity.nl

providing details and we will investigate your claim.
}

Copyright and moral rights for the publications made accessible in the public portal are retained by the authors and/or other copyright owners and it is a condition of accessing publications that users recognise and abide by the legal requirements associated with these

- Users may download and print one copy of any publication from the public portal for the purpose of private study or research.

- You may not further distribute the material or use it for any profit-making activity or commercial gain

If the publication is distributed under the terms of Article $25 \mathrm{fa}$ of the Dutch Copyright Act, indicated by the "Taverne" license above, 


\section{Maastricht University}

\section{Arbeidsmarktongelijkheid onder hbo'ers}

Hoe individuele achtergrondkenmerken van hbo'ers samenhangen met arbeidsmarktsucces op de korte en middellange termijn

\section{ROA Rapport}

ROA-R-2018/9

Researchcentrum voor Onderwijs en Arbeidsmarkt | ROA Research Centre for Education and the Labour Market / ROA 



\section{ARBEIDSMARKTONGELIJKHEID ONDER HBO'ERS}

Hoe individuele achtergrondkenmerken van hbo'ers samenhangen met arbeidsmarktsucces op de korte en middellange termijn

ROA-R-2018/9

Barbara Belfi

Jim Allen

Babs Jacobs

Kars van Oosterhout 
Colofon

(c) Researchcentrum voor Onderwijs en Arbeidsmarkt (ROA). Niets uit deze uitgave mag op enige manier worden verveelvoudigd zonder voorafgaande schriftelijke toestemming van de directeur van het ROA.

\section{Researchcentrum voor Onderwijs en Arbeidsmarkt}

Postbus 616

6200 MD Maastricht

$\mathrm{T}+31433883647$

$F+31433884914$

secretary-roa-sbe@maastrichtuniversity.nl

www.roa.nl

School of Business and Economics

Maastricht University

\section{Vormgeving}

ROA secretariaat, Maastricht

ISBN: 978-90-5321-570-8

december 2018 


\section{INHOUD}

2 Theoretisch kader 3

$\begin{array}{ll}2.1 & \text { Historisch context } \\ & 3\end{array}$

2.2 Ongelijkheden in arbeidsmarktpositie naar sociale herkomst, geslacht en migratieachtergrond $\quad 4$

2.3 Verklaringen voor de arbeidsmarktpositie van achtergestelde groepen 6

2.3.1 Het belang van opleidingssector in de onderwijs-arbeidsmarkt transitie 6

2.3.2 Het belang van sociaal kapitaal in de onderwijs-arbeidsmarkt transitie 9

2.3.3 Het belang van persoonlijkheidskenmerken en baanvoorkeuren in de $\begin{array}{ll}\text { onderwijs arbeidsmarkt transitie } & 10\end{array}$

3 Data en methode 15

$\begin{array}{ll}3.1 \text { Data } & 15\end{array}$

$\begin{array}{ll}3.2 & \text { Metingen } \\ 3.3 & 15\end{array}$

3.3 Beschrijvende statistieken van de drie deelpopulaties 16

3.3.1 Beschrijvende statistieken naar sociaaleconomische herkomst $\quad 17$

$\begin{array}{ll}\text { 3.4.2 Beschrijvende statistieken naar geslacht } & 17\end{array}$

3.4.3 Beschrijvende statistieken naar migratieachtergrond 20

4 Resultaten 23

4.1 Nadere analyse van de invloed van achtergrondkenmerken 23

$\begin{array}{ll}\text { 4.1.1 Ouderlijke afkomst } & 23\end{array}$

$\begin{array}{ll}\text { 4.1.2 Geslacht } & 25\end{array}$

4.1.3 Migratieachtergrond $\quad 26$

$\begin{array}{ll}\text { 4.2 De rol van de afzonderlijke verklarende factoren } & 28\end{array}$

5 Conclusie en discussie $\quad 37$

$\begin{array}{ll}\text { Literatuur } & 41\end{array}$

Bijlage A: Gebruikte schalen voor nieuwe uitdagingen, materiële ambitie en sociaal netwerk 



\section{BELANGRIJKSTE BEVINDINGEN EN CONCLUSIES}

\section{Historische scheidslijnen}

Historisch gezien vormen sociale herkomst, geslacht, en migratieachtergrond belangrijke scheidslijnen in het onderwijs en op de arbeidsmarkt. Door de onderwijsexpansie is de deelname van deze traditioneel kwetsbare groepen in het hoger (beroeps)onderwijs sterk gestegen. In dit rapport onderzoeken we of de loopbanen van afgestudeerde hbo'ers uit deze groepen hierdoor beter verlopen, of nog steeds getekend worden door verschillen in carrièreontwikkeling in vergelijking met afgestudeerde hbo'ers uit traditioneel geprivilegieerde groepen.

\section{Sociale herkomst speelt na het behalen van een hbo-diploma geen rol meer}

Sociale herkomst - het opleidingsniveau van de ouders - blijkt uit onze analyses geen rol van betekenis te spelen bij het bepalen van arbeidsmarktuitkomsten van hboafgestudeerden. Dit betekent niet per se dat sociale herkomst er niet toedoet op de Nederlandse arbeidsmarkt, omdat er nog altijd sprake is van differentiatie naar sociale herkomst in de doorstroom vanuit het middelbare naar het hogere onderwijs. Echter, als jongeren uit lagere milieus eenmaal voor een hbo-opleiding hebben gekozen en deze succesvol hebben afgerond, blijken ze zich daarmee effectief te hebben losgemaakt van een eventueel nadeel op de arbeidsmarkt.

\section{Man-vrouw verschillen blijven hardnekkig bestaan}

Het carrièreverloop van mannen en vrouwen blijkt wel fors te verschillen, zowel op korte als op middellange termijn. Hoewel vrouwen in de eerste vier tot acht jaar na afstuderen een deel van hun initiële achterstand op aspecten als baantevredenheid en vast contract weten in te halen, neemt hun achterstand ten opzichte van mannen juist toe op aspecten als uurloon en baankansen. Vooral de groeiende beloningskloof - van een $5 \%$ uurloonnadeel kort na afstuderen tot maar liefst een 12\% achterstand vier tot acht jaar na afstuderen - is zorgwekkend. Wanneer we hierbij ook het grote - en in de loop van de carrière - groeiende verschil in gewerkte uren tussen mannen en vrouwen meerekenen, wordt duidelijk dat vrouwelijke afgestudeerde hbo'ers op maandbasis veel minder te besteden hebben dan mannen met een vergelijkbare opleiding. 
Vrouwen betalen een prijs voor het werken in deeltijd

Een belangrijk deel van de nadelige arbeidsmarktpositie van vrouwen op korte en middellange termijn, kan worden toegeschreven aan het werken in deeltijd. Een groot deel van het negatieve effect van geslacht op vaste aanstellingen, baanmatch en baantevredenheid kan hierdoor worden verklaard. Hoewel deeltijdwerk niet in staat is om verschillen in uurloon te verklaren, is duidelijk dat minder gewerkte uren doorgaans ook een minder riant maandloon betekenen. Deze resultaten onderstrepen het feit dat de deeltijdstatus van veel vrouwelijke hbo'ers met een fors prijskaartje gepaard gaat.

\section{Gezinszorg vormt vooralsnog geen barrière voor vrouwelijke hbo'ers}

Enigszins tegen de verwachtingen in bleken gezinsvorming en zorgtaken hooguit een marginale rol te spelen bij de slechtere arbeidsmarktpositie van vrouwen op zowel korte als middellange termijn. Hoewel veel vrouwelijke afgestudeerde hbo'ers vier tot acht jaar na afstuderen reeds kinderen hebben en veel meer tijd aan zorgtaken besteden dan mannelijke hbo'ers, vonden we nauwelijks steun voor de verwachting dat dit een belangrijke barrière vormt voor hun carrièreontwikkeling.

\section{Hbo'ers met een niet-westerse migratieachtergrond ondervinden vooral problemen bij het vinden van werk \\ De nadelige positie van afgestudeerden met een niet-westerse migratieachtergrond blijkt vooral in hun structureel veel lagere kans op werk te zitten. In termen van objec- tieve baankenmerken als werkzekerheid, baanmatch en beloning zijn ze ongeveer even succesvol als afgestudeerden met een Nederlandse achtergrond, al zijn ze iets minder tevreden met hun werk. Niet-westerse afgestudeerden halen in de loop van de tijd wel een deel van hun achterstand in, maar vier tot acht jaar na afstuderen zijn de verschillen in baankansen en baantevredenheid nog steeds significant.}

\section{Sectorkeuze speelt bij afgestudeerden met een niet-westerse achtergrond een belangrijke rol}

Een belangrijk deel van de nadelige positie van afgestudeerde hbo'ers met een nietwesterse migratieachtergrond in termen van kans op werk en baantevredenheid kan worden toegeschreven aan de opleidingssectorkeuze. Uit ons onderzoek blijkt dat afgestudeerden met een niet-westerse migratieachtergrond relatief vaak voor de opleidingssectoren social studies en economie kiezen, en minder vaak voor Onderwijs, Zorg en technische studies. Echter, uit recent onderzoek van het ROA blijkt dat er op dit moment juist veel vraag is naar hoogopgeleid personeel in de Techniek, Gezondheidszorg en het Onderwijs. Tegelijkertijd zijn de startposities voor de studierichtingen waar nietwesterse afgestudeerden hbo'ers migratieachtergrond wel voor kiezen, zoals Economie, op dit moment relatief minder goed (Bakens, Fouarge, \& Peeters, 2018). Op de middellange termijn is de lagere kans op werk van niet-westerse afgestudeerden ook medebepaald door hun lagere kans op werk op korte termijn, al blijft er nog een substantieel onverklaard effect nog over. 


\section{INLEIDING}

In dit rapport wordt onderzocht in hoeverre individuele achtergrondkenmerken zoals geslacht, sociale herkomst en migratieachtergrond samenhangen met de arbeidsmarktontwikkelingen die jonge afgestudeerde hbo'ers doormaken gedurende de eerste vier tot acht jaar na afstuderen. Hiervoor wordt gebruik gemaakt van data afkomstig van de HBO-Monitor, een jaarlijks onderzoek van het Researchcentrum voor Onderwijs en de Arbeidsmarkt (ROA) en de Vereniging Hogescholen (VH). In de HBO-Monitor worden afgestudeerden van het hoger beroepsonderwijs (hbo) bevraagd over hun arbeidsmarktpositie en studietevredenheid. Naast kennis over de eerste banen waarin hbo'ers terecht komen, wordt met behulp van deze monitor tevens inzicht verkregen in de studie-ervaringen van afgestudeerden, de aansluiting tussen de gevolgde studie en de arbeidsmarkt en de benodigde competenties in de praktijk.

Naast de reguliere meting, die één jaar na afstuderen plaatsvindt is in 2015 tevens een meting uitgevoerd onder afgestudeerde hbo'ers vier tot acht jaar na afstuderen. Het gaat hierbij om hbo'ers die eerder hebben meegedaan aan de reguliere meting en zijn afgestudeerd tussen 2007 en 2011. Met deze gegevens is het mogelijk om meer zicht te krijgen op de carrière van hbo'ers op de middellange termijn. Over de loopbaanontwikkelingen van hbo'ers in de eerste vijf jaar na afstuderen is eerder al gerapporteerd (Allen, Belfi en Mommers, 2016). Hieruit kwam onder andere naar voren dat van de helft van de hbo'ers die ten tijde van de eerste meting (i.e. één jaar na afstuderen) werkloos waren, ten tijde van de tweede meting (vijf jaar na afstuderen in dit geval) inmiddels een baan op niveau had gevonden. Daarnaast bleek dat het aantal afgestudeerden met een vaste aanstelling fors was toegenomen tussen de twee metingen (van 62\% naar $86 \%$ ) en dat men over het algemeen beduidend positiever was geworden over de gevolgde hboopleiding (+3\%).

In dit tweede rapport, zal ter verdieping op het eerste rapport nader worden ingegaan op de arbeidsmarktpositie van kwetsbare groepen in de samenleving. Sociale herkomst, geslacht, en migratieachtergrond vormen historisch gezien belangrijke scheidslijnen in het onderwijs en op de arbeidsmarkt (Dumais, 2002). In dit rapport gaan wij na in hoeverre deze scheidslijnen (nog steeds) van invloed zijn op de carrièreontwikkeling van afgestudeerde hbo'ers. Het is om meerdere redenen van belang om te weten in hoeverre carrièreontwikkelingen verschillen naargelang individuele achtergrondkenmerken. Allereerst is het vanuit zowel individueel als maatschappelijk oogpunt van belang dat 
alle afgestudeerde hbo'ers de kans krijgen om de in het hoger beroepsonderwijs opgedane kennis en vaardigheden zo volledig mogelijk te benutten op de arbeidsmarkt (Salverda, 2015). Indien sommige groepen afgestudeerden vaker worden gedwongen om bijvoorbeeld onder hun niveau of in deeltijd te werken, zouden ze minder productief zijn dan op basis van de verworven vaardigheden in het hbo kan worden verwacht, waardoor zowel individuele als maatschappelijke opbrengsten worden misgelopen. Ten tweede kan een dergelijke onderbenutting van vaardigheden vroeg in de arbeidsloopbaan doorwerken in de verdere carrière. Het is belangrijk om te weten of deelpopulaties die met een achterstand aan hun loopbaan beginnen, er in slagen om deze achterstand later in de carrière in te halen, of juist steeds verder achteropraken ten opzichte van deelpopulaties met een gunstigere start op de arbeidsmarkt.

Op basis van de gegevens van de twee metingen (één jaar en vier tot acht jaar na afstuderen) onder dezelfde groep afgestudeerde hbo'ers zullen de volgende vragen worden beantwoord:

1. In hoeverre hangt de loopbaanontwikkeling van hbo'ers in de eerste jaren na afstuderen samen met sociale herkomst, geslacht, en migratieachtergrond?

2. Hoe kunnen mogelijke verschillen in loopbaanontwikkeling tussen kwetsbare en bevoorrechte groepen hbo'ers in de eerste jaren na afstuderen worden verklaard door verschillen in opleidingssector, sociaal kapitaal en persoonlijkheids- en baankenmerken?

De opbouw van dit rapport is als volgt. Allereerst presenteren we een theoretisch kader met daarin wetenschappelijke theorieën en bevindingen over de arbeidsmarktontwikkelingen van traditioneel kwetsbare versus traditioneel bevoorrechte groepen. Op basis van dit theoretische kader worden vervolgens een aantal hypothesen opgesteld. Hierna lichten we de gebruikte data en onderzoeksmethode toe en gaan we in op de resultaten van ons onderzoek. Mogelijke verklaringen voor verschillen in arbeidsmarktuitkomsten tussen eerdergenoemde deelpopulaties worden hierbij besproken. Voorts worden in de conclusie de belangrijkste bevindingen nog eens samengevat. Daarbij gaan wij ook in op hoe onze bevindingen zich verhouden tot eerder onderzoek naar dit onderwerp. 


\section{THEORETISCH KADER}

\subsection{Historisch context}

Mede door de onderwijsexpansie van de afgelopen decennia, zijn steeds meer vrouwen en jongeren uit lagere sociale milieus en/of met een migratieachtergrond toegetreden in het hoger beroepsonderwijs. Het is niet helemaal duidelijk hoe deze expansie doorwerkt op de arbeidsmarkt in termen van succeskansen van verschillende groepen afgestudeerden. Historisch gezien kennen mensen uit lagere socio-economische milieus, vrouwen en mensen met een migratieachtergrond elk een achtergestelde positie. Het toegenomen opleidingsniveau van deze deelpopulaties zou op zichzelf tot een verbetering in arbeidsmarktpositie moeten leiden, maar minder duidelijk is in hoeverre zij erin slagen om deze stijging in kwalificaties op de arbeidsmarkt te verzilveren. Zowel de sociologische moderniseringsthese (Blau \& Duncan, 1967) als de economische menselijk kapitaal theorie (Becker, 1964) gaan uit van de verwachting dat in de huidige samenleving, mensen vooral worden beoordeeld op de arbeidsmarkt op basis van kennis en kwalificaties, en niet op basis van achtergrondkenmerken als geslacht, migratieachtergrond en sociaaleconomische herkomst (Tolsma \& Wolbers, 2014). Tegelijkertijd zorgt de groei van het aantal afgestudeerde hbo'ers ervoor dat een hbo-diploma steeds minder onderscheidend is op de arbeidsmarkt (van de Werfhorst, 2001), waardoor naast kennis en kwalificaties, ook andere factoren een rol zijn gaan spelen bij het verdelen van afgestudeerden met dezelfde opleidingsniveau over banen van uiteenlopende kwaliteit.

Er zijn veel indicaties dat de groepen afgestudeerden die het historisch gezien moeilijk hebben gehad op de arbeidsmarkt nog steeds een achterstandspositie kennen gedurende de transitie van het onderwijs naar de arbeidsmarkt (Argentin en Triventi, 2011, CBS,2016a). Er is echter nog weinig bekend over hoe deze initiële achterstand op de arbeidsmarkt uitpakt voor de verdere loopbaan. Dit zorgwekkend aangezien uit veel studies blijkt dat de transitie van het hoger beroepsonderwijs naar de arbeidsmarkt op zichzelf al een belangrijke voorspeller is voor de toekomstige carrière van jongvolwassenen (Scherer, 2004; Verbruggen et al., 2015). Zo blijken afgestudeerden die er langer over doen om hun eerste baan te vinden vele jaren later minder te verdienen dan afgestudeerden die hier korter over doen (Gartell, 2009; Bell \& Blanchflower, 2011). Daarnaast hebben ook een functie onder het eigen opleidingsniveau (Baert, Cockx, \& Verhaest, 2013; Verbruggen et al., 2015), flexibel werk (Verbruggen et al., 2015) en een laag uurloon (Steward, 2007) in de eerste baan een nadelig effect op de verdere carrière. 
Dergelijke ongunstige ervaringen gedurende de eerste baan worden door latere werkgevers immers meegenomen in hun beslissing om iemand aan te nemen (McCormick, 1990; Kroft et al., 2013; Eriksson \& Rooth, 2014). Daarnaast blijken afgestudeerden met een eerste baan onder opleidingsniveau minder leermogelijkheden te hebben in hun latere loopbaan (Büchel, \& Mertens, 2004; Ferreira et al., 2017) en achteruit te gaan in hun cognitieve vaardigheden (de Grip et al., 2008). Het belang van een vlotte overgang van studie naar werk is dan ook de reden dat veel arbeidsmarktstudies zich focussen op de eerste stappen van afgestudeerden op de arbeidsmarkt (Bradley \& Nguyen, 2004).

Wanneer afgestudeerden uit lager milieus, vrouwen en mensen met een migratieachtergrond al een achterstand kennen bij het betreden van de arbeidsmarkt, zou dit initieel nadeel blijvend kunnen doorwerken in hun verdere carrière. Onduidelijk is echter in hoeverre dergelijke 'scarring'-effecten verschillen tussen deelpopulaties. De weinige studies die dit hebben onderzocht spreken elkaar vaak tegen. Zo laat onderzoek naar de effecten van intredewerkloosheid onder recent afgestudeerden in Zweden zien, dat vrouwen en niet-Europese immigranten meer nadeel hiervan ondervinden op hun latere inkomen dan mannen en autochtone Zweden (Gartell, 2009). Tegelijkertijd laat een onderzoek onder een soortgelijke populatie (Nordström \& Skans, 2011) zien dat de scarring-effecten van werkloosheid kort na afstuderen gelijk zijn voor verschillende deelpopulaties.

In dit rapport gaan we allereerst na hoe de arbeidsmarktpositie van verschillende deelpopulaties van elkaar verschillen één jaar na afstuderen. Vervolgens gaan we na in hoeverre eventuele initiële verschillen in arbeidsmarktpositie tussen verschillende deelpopulaties doorwerken in arbeidsmarktcarrière op de middellange termijn (vier tot acht jaar na afstuderen) Om licht te werpen op mogelijke oorzaken van verschillen in loopbaanontwikkeling, onderzoeken we de rol van drie factoren die hiervoor mogelijk een verklaring voor kunnen bieden: opleidingskeuze, sociaal kapitaal en persoonlijke voorkeuren.

\subsection{Ongelijkheden in arbeidsmarktpositie naar sociale herkomst, geslacht en migratieachtergrond}

\section{Sociale herkomst}

In het klassieke statusverwervingsmodel van Blau en Duncan (1967) werd al het verband gelegd tussen de opleiding en beroepsstatus van vaders en die van hun zonen. Deze invloed zou de laatste decennia door de modernisering van de samenleving sterk zijn afgenomen. Dankzij de bijbehorende expansie en democratisering van het hoger onderwijs werd studeren ook toegankelijk voor jongeren met een lage sociale herkomst. Ook op de arbeidsmarkt is ongelijkheid in sociale afkomst sterk afgenomen in de laatste decennia, onder andere doordat werkgevers meer op onderwijsprestaties zouden zijn gaan selecteren. 
Toch hebben kinderen van laagopgeleide ouders nog vaak een achterstand, niet alleen binnen het onderwijs (Tieben \& Wolbers, 2010; Triventi, 2013b), maar ook op de arbeidsmarkt. Zo blijkt sociale herkomst nog altijd gerelateerd te zijn aan inkomen (Triventi, 2013a), de kans op werk (Caspi et al., 1998) het prestige van de baan, hogere baantevredenheid (Mora et al., 2007), meer werkzekerheid (Argentin \& Triventi, 2011; Ballarino \& Bernandi, 2016; Triventi, 2013a). Deze effecten worden ook gevonden wanneer specifiek gekeken wordt naar hoogopgeleiden (Jacob et al., 2015). Ondanks de modernisering van de arbeidsmarkt in de laatste decennia is de verwachting daarom dat: sociale herkomst nog steeds positief is gerelateerd aan de arbeidsmarktpositie onder hbo-afgestudeerden, zowel op korte als op middellange termijn $\left(\mathrm{H}_{1}\right)$.

\section{Geslacht}

Ook de positie van vrouwen zou in de afgelopen decennia sterk zijn verbeterd. Zo stond kort na de Tweede Wereld Oorlog het idee van de werkende vrouw ter discussie en werden getrouwde vrouwen uitgesloten van overheidsbanen (Ruijters, 1981). Door de modernisering van de samenleving is de houding ten opzichte van werkende vrouwen tegenwoordig veel positiever, hetgeen tot uitdrukking komt in o.a. regelgeving omtrent zwangerschapsverlof, en overheidscampagnes gericht op het bevorderen van opleiding en arbeidsparticipatie van vrouwen in sectoren waarin vrouwen traditioneel sterk zijn ondervertegenwoordigd 9zoals bèatechniek). Ook werkgevers zijn positiever tegen vrouwelijke werknemers aan gaan kijken, al blijven bepaalde hardnekkige denkbeelden op de werkvloer bestaan (CBS, 2018). Genderverschillen in het onderwijs zijn het snelst veranderd. Waar vrouwen historisch gezien werden geweigerd op universiteiten (Ruijters, 1981) is hun participatie de afgelopen decennia sterk gestegen en studeren er inmiddels meer vrouwen dan mannen in het hoger onderwijs (CBS, 2018).

De positie van vrouwen op de arbeidsmarkt lijkt derhalve over het algemeen te zijn verbeterd over de afgelopen decennia, waardoor hun achterstand in termen van beroepsstatus (Tolsma \& Wolbers, 2010, 2016), leidinggeven en uurloon zijn afgenomen is (CBS, 2016a). Toch blijken mannen nog altijd meer te verdienen (CBS, 2016a), een hogere kans op werk te hebben (SCP/CBS, 2016) en vaker leiding te geven dan vrouwen (CBS, 2016a). Opvallend is dat ondanks dat vrouwen vaker op lagere posities werken en minder beloond worden dan mannen, zij evenveel voldoening te halen uit hun werk (Sousa-Poza \& Sousa-Poza, 2000; Mora et al., 2007). Desondanks verwachten we dat: over het algemeen vrouwelijke hbo-afgestudeerden gemiddeld een slechtere arbeidsmarktpositie kennen dan mannelijke hbo-afgestudeerden, zowel op korte als op middellange termijn $\left(\mathrm{H}_{2}\right)$.

\section{Migratieachtergrond}

Kinderen met een migratieachtergrond blijken het over het algemeen lastiger in het onderwijs te hebben dan kinderen zonder migratieachtergrond (CBS, 2016b), en minder door te stromen naar het hoger onderwijs. Dit blijkt over de jaren heen maar weinig te zijn veranderd. Het aantal hbo-studenten met migratieachtergrond is weliswaar sterk toegenomen maar dit is vooral gerelateerd aan een gestegen aandeel mensen met een migratieachtergrond in de samenleving in het algemeen. De kans om als jongere met 
een migratieachtergrond aan een opleiding in het hoger onderwijs te beginnen is in vergelijking met jongeren zonder migratieachtergrond niet veranderd gedurende de voorbije decennia (Tolsma, Coenders \& Lubbers, 2007.

Deze ongelijkheid naar migratieachtergrond zet zich voort op de arbeidsmarkt (CBS, 2016b). Zo is de arbeidsmarktpositie van hbo-afgestudeerden met een migratieachtergrond slechter dan de positie van hbo-afgestudeerden zonder een migratieachtergrond (Meng et al., 2014). Deze ongelijkheid is deels te verklaren doordat migratieachtergrond samenhangt met andere succesfactoren op de arbeidsmarkt zoals sociale herkomst. Echter, ook wanneer rekening wordt gehouden met dergelijke factoren blijft er sprake van een 'etnische straf' (in het Engels: ethnic penalty) op de arbeidsmarkt (Kalter \& Kogan, 2004; Meng et al., 2014), vooral voor afgestudeerden met een niet-westerse migratieachtergrond. Dit komt tot uitdrukking in een veel hogere werkloosheid (CBS, 2016b; Meng et al., 2014), een lagere kans op een baan op minimaal hbo-niveau en een lagere baantevredenheid (ROA, 2016; van Gent et al., 2006). Opvallend is dat de positie van afgestudeerden met een Westerse migratieachtergrond vaak juist positief opvalt. Zij vinden even vaak een baan op niveau als autochtonen en kennen een hoge baantevredenheid (van Gent et al., 2006). De verwachting is dan ook dat: hbo-afgestudeerden met een niet-westerse migratieachtergrond gemiddeld een slechtere arbeidsmarktpositie kennen dan hbo-afgestudeerden zonder een migratieachtergrond of met een Westerse migratieachtergrond, zowel op korte als op middellange termijn $\left(\mathrm{H}_{3}\right)$.

\subsection{Verklaringen voor de arbeidsmarktpositie van achtergestelde groepen}

Op basis van het onderzoek dat we in de vorige paragraaf hebben besproken, verwachten we dat de drie van oudsher kwetsbare deelpopulaties (jongeren met laagopgeleide ouders, vrouwen en jongeren met een migratieachtergrond) die het huidige onderzoek centraal staan, ook vandaag de dag nog kampen met een achterstand op de arbeidsmarkt. In dit hoofdstuk opperen wij drie verklaringen voor deze groepsverschillen. Als eerste kijken we naar de rol van de opleidingssector waarin de afgestudeerden zijn afgestudeerd, aangezien sommige opleidingssectoren een goede start op de arbeidsmarkt vergemakkelijken of juist vermoeilijken. Traditioneel bevoorrechte groepen zouden via deze studiekeuze hun privilegieerde positie proberen door te geven aan de volgende generatie. Daarnaast kijken we naar de rol van sociaal kapitaal. Indien afgestudeerden uit bevoorrechte groepen vanuit hun sociale netwerk over meer hulpbronnen beschikken, kan dit voordeel opleveren op de arbeidsmarkt. Als laatste verwachten dat groepsverschillen in arbeidsmarktpositie mogelijk zijn terug te voeren op de persoonlijke voorkeuren van afgestudeerden wanneer zij zoeken naar een baan.

\subsubsection{Het belang van opleidingssector in de onderwijs-arbeidsmarkt transitie}

Het ROA laat aan de hand van haar jaarlijkse HBO-Monitor en periodieke arbeidsmarktvoorspellingen zien dat arbeidsmarktperspectieven sterk kunnen verschillen tussen opleidingsrichtingen (Allen, Belfi \& Mommers, 2016; ROA, 2018a; 2018b). Afstuderen in de juiste opleidingsrichting of -sector kan dus een belangrijke voorsprong geven op de 
arbeidsmarkt. Dit is consistent met het beeld dat uit andere Europese landen naar voren komt. Zo is er in veel landen sprake van grote verschillen tussen opleidingssectoren in latere werkloosheid en baanprestige (Reimer et al.,2008), inkomen (Triventi, 2013b), de kans op een vast contract (Giesecke, \& Schindler, 2008) en over-educatie (Ortiz \& Kucel, 2008). Daarnaast kan de opleidingskeuze ook gevolgen hebben voor de latere baantevredenheid (Vila et al., 2007).

Jongeren laten zich in hun studiekeuze niet alleen leiden door hun eigen capaciteiten en de arbeidsmarktperspectieven van opleidingen, maar worden ook beïnvloed door hun sociale omgeving. Zo kunnen ouders kinderen al tijdens de opvoeding bepaalde voorkeuren of verwachtingen aanleren die zich later in de studiekeuze uiten (van de Werfhorst, 2001). Jongeren blijken sowieso vaak te kiezen voor een studierichting die hun ouders ook hebben gevolgd (van de Werfhorst, de Graaf en Kraaykamp, 2001). Ook kunnen ouders en anderen, zoals familie, leraren en vrienden, direct advies geven over welke opleidingsrichting zij denken dat het beste bij de jongere past, of kunnen jongeren een studie kiezen omdat veel van hun vrienden dezelfde studie gaan volgen. Deze directe en indirecte vormen van sturing kunnen ertoe leiden dat jongeren uit bevoorrechte groepen vaker worden aangespoord om een studierichting met goede baankansen te kiezen, terwijl jongeren uit achtergestelde groepen meer in de richting van opleidingen met mindere gunstige arbeidsmarktkansen worden gestuurd. Via dergelijke mechanismen blijven sociale scheidslijnen in stand en krijgen afgestudeerden uit achterstelde groepen al snel te maken met een achterstand op de arbeidsmarkt.

\section{De relatie tussen opleidingskeuze en sociale herkomst}

De 'effectively maintained inequality thesis' (Lucas, 2001) stelt dat met name na de onderwijsexpansie in het hoger onderwijs de aandacht van de hoge sociale klasse voor de keuze tussen opleidingsrichtingen of -sectoren is toegenomen (Kraaykamp et al., 2013). Omdat het beschikken over een hbo-diploma minder onderscheidend is geworden, proberen hoger opgeleide ouders hun kinderen onder te brengen bij de meest renderende opleidingsrichtingen. Deze theorie wordt ondersteund door verschillende empirische studies, die inderdaad aantonen dat kinderen met een bevoorrechte sociale achtergrond oververtegenwoordigd zijn in opleidingssectoren met een hoog prestige (Triventi, 2013a, 2103b; Duru-Bellat et al., 2008; Van de Werfhorst 2002; Werfhorst en Luijkx 2010).

Andere studies bieden voor deze verwachting echter minder steun. Zo blijkt dat de specifieke studierichtingen die jongeren met hoogopgeleide ouders kiezen verschillen tussen landen (Triventi, 2013b) en zijn de verschillen ten opzichte van jongeren met laagopgeleide ouders vaak bescheiden (zie Triventi et al., 2017). Verder biedt volgens Jackson en anderen (2008) de opleidingskeuze van afgestudeerden geen verklaring voor verschillen in inkomen tussen afgestudeerden met laagopgeleide en hoogopgeleide ouders in het algemeen, al vinden zij wel een bescheiden effect in Nederland. Ook andere studies lijken uit te wijzen dat, hoewel de verwachtingen van 'effectively maintained inequality thesis' niet in alle landen blijken op te gaan, dit in Nederland wel het 
geval is. We verwachten daarom dat: opleidingssector een gedeeltelijke verklaring biedt voor de verschillen in arbeidsmarktuitkomsten tussen hbo-afgestudeerden met laagopgeleide en hoogopgeleide ouders $\left(\mathrm{H}_{4} \mathrm{a}\right)$.

\section{De relatie tussen opleidingskeuze en geslacht}

Ook verschillen in de arbeidsmarktpositie tussen mannen en vrouwen worden vaak verklaard aan de hand van verschillen in opleidingsrichting of -sector. Het 'culturalistisch' perspectief (Barone, 2011; Eccles, 2011) stelt dat kinderen opgroeien met bepaalde geslachtsspecifieke verwachtingen, bijvoorbeeld dat een verzorgende rol meer iets is voor meisjes dan voor jongens. Deze stereotypering werkt door in het (hoger) onderwijs, waarbij vrouwen en mannen vaker voor studies kiezen die aansluiten bij hun toegeschreven rolpatronen (Barone, 2011; Smyth \& Steinmetz, 2008, p. 260). Dit betekent dat vrouwen vaker voor sociale en zorg-gerelateerde studies kiezen, terwijl mannen vaker in studies in economische en technische richtingen terecht komen. De 'devaluatie hypothese' stelt verder dat wanneer bepaalde richtingen voornamelijk worden gekozen door vrouwen, de bijbehorende beroepen minder aanzien hebben (Tam, 1997). Culturele vooroordelen over zogenaamde 'vrouwenopleidingen' en 'vrouwenberoepen' kunnen verschillen in de arbeidsmarktpositie tussen mannen en vrouwen mogelijk dus verklaren.

Deze verwachtingen vinden veel steun in de empirische literatuur. Zo blijken soortgelijke verschillen in opleidingsrichting tussen mannen en vrouwen te bestaan in vrijwel elk onderzocht land (Barone, 2011; Berggen, 2001; van de Werfhorst et al., Cheung, 2003; Borghans \& Groot 1999). Deze sekseverschillen in opleidingsrichting dragen vervolgens weer bij aan een gesegregeerde arbeidsmarkt met vrouwenberoepen en mannenberoepen (Smyth \& Steinmetz, 2008). We verwachten daarom dat: opleidingssector een gedeeltelijke verklaring biedt oor de verschillen in arbeidsmarktuitkomsten tussen vrouwelijke en mannelijke hbo-afgestudeerden $\left(\mathrm{H}_{4} b\right)$.

\section{De relatie tussen opleidingskeuze en migratieachtergrond}

Uit onderzoek is gebleken dat hoogopgeleiden met een migratieachtergrond vaker afstuderen in studies als rechten en economie, en minder vaak voor onderwijs, zorg en technische studies kiezen (Van den Berg et al., 2001; Jennissen \& Oudhof, 2007). Deze voorkeuren zijn wellicht deels gebaseerd op vooroordelen, waarbij migranten technische studies en de gezondheidszorg met handenarbeid associëren en daardoor minder waarderen (Elfering, van Kuijk, \& Mommers, 2014), en meer oog hebben voor studies die als prestigieuzer worden beschouwd, en die opleiden tot 'witteboordenberoepen', zoals economie en rechten (Koning et al, 2010; Sören, 2009).

Ook zouden systematische verschillen in persoonlijke voorkeuren (zie paragraaf 2.3.3 voor een uitgebreidere beschouwing van het mogelijk effect hiervan) ertoe kunnen leiden dat migranten vaker voor opleidingen kiezen waarvan ze verwachten dat ze meer toegang bieden tot goedbetaalde banen. Het valt echter te betwijfelen of deze voorkeuren van jongeren met een migratieachtergrond zich daadwerkelijk uitbetalen 
op de arbeidsmarkt. Waar eerdere studies aangaven dat de studiekeuze van migrantenjongeren hen inderdaad de beoogde baankansen oplevert (van Gent et al., 2006, p.3), lijkt dit effect de afgelopen jaren te zijn omgeslagen. Zo is er op dit moment veel vraag naar hoogopgeleid technisch personeel en onderwijzers, sectoren waarin migranten ondervertegenwoordigd zijn. Tegelijkertijd zijn de startposities voor de studierichtingen waar zij wel voor kiezen, zoals economie, op dit moment relatief minder goed (Bakens, Fouarge, \& Peeters, 2018). We verwachten daarom dat: opleidingssector een gedeeltelijke verklaring biedt voor de verschillen in arbeidsmarktuitkomsten tussen hbo-afgestudeerden met migratieachtergrond en hbo-afgestudeerden zonder een migratie-achtergrond $\left(\mathrm{H}_{4} \mathrm{C}\right)$.

\subsubsection{Het belang van sociaal kapitaal in de onderwijs-arbeidsmarkt transitie}

Jongeren kunnen bij het zoeken naar een geschikte plek op de arbeidsmarkt vaak een beroep doen op hun vrienden, familie en kennissen. Niet iedereen schikt echter over een even sterk sociaal netwerk in termen van sociale contacten dat men kan inzetten om de transitie naar de arbeidsmarkt te versoepelen. Verschillen in het hebben van dergelijke sociale contacten worden in de literatuur als verschillen in sociaal kapitaal omschreven (Coleman, 1988). Sociaal kapitaal vormt een belangrijke bron van informatie over baanmogelijkheden en kan van belang zijn voor het bemachtigen van een baan, bijvoorbeeld door het geven van een referentie (Lin, 1999). Verschillende studies vinden dan ook dat afgestudeerden vaak via sociale contacten aan hun baan komen, en dat mensen met veel sociaal kapitaal vaak een goede baan hebben (Boxman \& Flap, 2017).

Personen met een geprivilegieerde achtergrond beschikken vaak over meer sociaal kapitaal dan afgestudeerden met een minder gunstige achtergrond (Lin, 2000). Van belang is uiteraard dat dit 'kapitaal' ook daadwerkelijk gemobiliseerd kan worden (Bourdieu, 1986). Sociale connecties moeten ook daadwerkelijk bereidt zijn informatie te delen en te helpen in de zoektocht naar een baan, willen ze van nut zijn voor de werkzoekende. Zelfs wanneer afgestudeerden uit achtergestelde groepen goede contacten hebben, is niet altijd evident dat deze even bereid zijn om voor hen hun nek uit te steken als voor geprivilegieerde groepen (zie bijvoorbeeld Smith, 2000).

\section{De relatie tussen sociaal kapitaal en sociale herkomst}

Het CBS (2014) laat zien dat opleidingsniveau de grootste scheidslijn is wat betreft sociaal kapitaal. Hoogopgeleide ouders hebben gemiddeld genomen dus meer sociaal kapitaal dan laagopgeleide ouders, en daarmee een groter sociaal netwerk dat informatie en steun kan verlenen om hun kinderen aan een baan te helpen (Lin et al., 1981). Ook jongeren van een hoge sociale afkomst zelf blijken gemiddeld genomen over een groter sociaal kapitaal te beschikken dan jongeren van een lage sociale herkomst (Quiteet al., 2013), bijvoorbeeld in de vorm van lidmaatschap van een vereniging (van Houten, Gesthuizen en Wolbers, 2012), of door het feit dat zij eerder een beroep kunnen doen op mensen met een hoge sociale status (Lin, Ensel en Vaughn, 1981). Om deze redenen verwachten we dat: sociaal kapitaal een gedeeltelijke verklaring biedt voor eventuele verschillen in arbeidsmarktuitkomsten tussen hbo-afgestudeerden met laagopgeleide ouders en hoogopgeleide ouders ( $\left.\mathrm{H}_{5} \mathrm{a}\right)$. 


\section{De relatie tussen sociaal kapitaal en geslacht}

Hoewel onderzoek naar het aantal sociale contacten over het algemeen geen verschil laat zien tussen mannen en vrouwen, blijken mannen gemiddeld wel meer nuttige contacten te hebben die hun van arbeidsmarktinformatie voorzien of bereid zijn hen aan te bevelen (Lin, 2000; Smith, 2000). Ondanks een even groot netwerk beschikken mannen dus over meer sociaal kapitaal dan vrouwen. Hoewel vrouwen en mannen zijn even vaak lid zijn van verenigingen, zijn de verenigingen waar vrouwen lid van zijn vaak kleiner van aard en minder gericht op economische activiteiten (McPherson en SmithLovin 1982). Vrouwennetwerken bestaan bovendien vaker uit niet-werkenden, familieleden en buren, terwijl mannennetwerken vaak diverser zijn, met veel leidinggevenden en mensen met een hogere status (Smith, 2000; Verhouwen, Jansen en Tazelaar, 2000). We verwachten daarom dat: verschillen in sociaal kapitaal vormen een gedeeltelijke verklaring voor de verschillen in arbeidsmarktuitkomsten tussen vrouwelijke en mannelijke hboafgestudeerden $\left(\mathrm{H}_{5} b\right)$.

\section{De relatie tussen sociaal kapitaal en migratieachtergrond}

Het sociale netwerk speelt een relatief grote rol onder afgestudeerden met een migratieachtergrond (Seibel \& van Tubergen, 2013; van Gent et al, 2004). Veel van hen achten het kansrijk om via deze zoekmethode aan een baan te komen, mogelijk omdat zij verwachten op deze manier minder met discriminatie te maken te krijgen (Mouw, 2002). Het sociaal kapitaal waarover deze afgestudeerden beschikken blijkt echter vaak weinig aansluiting te hebben met de arbeidsmarkt, omdat hun netwerken vaak kleiner zijn (Van Tubergen 2014) en relatief weinig hoogopgeleide en autochtonen bevatten (Kanas, Van Tubergen, \& Van der Lippe, 2011; Lancee, 2012). Uit Amerikaans onderzoek (Smith 2005) blijkt bovendien dat sociale contacten soms aarzelen om etnische minderheden aan te bevelen. We verwachten daarom dat: verschillen in sociaal kapitaal een gedeeltelijke verklaringen biedt voor de verschillen in arbeidsmarktuitkomsten tussen hbo-afgestudeerden met migratieachtergrond en hbo-afgestudeerden zonder een migratie-achtergrond ( $\mathrm{H}_{5 \mathrm{C}}$ ).

\subsubsection{Het belang van persoonlijkheidskenmerken en baanvoorkeuren in de onderwijs arbeidsmarkt transitie}

Tot slot kunnen afgestudeerden in verschillende banen terecht komen doordat zij verschillende persoonlijke voorkeuren hebben, zoals de bereidheid om risico te nemen, de preferentie voor een hoge materiele beloning of de behoefte aan veel inhoudelijke uitdagingen. Zo wordt binnen de economische theorie aangenomen dat iemand met een lage risicobereidheid eerder akkoord gaat met een lager loon om zeker te zijn dat hij of zij "onder de pannen" zit (Pissarides, 1974). Afgestudeerden die meer risico's durven nemen zullen salarisonderhandelingen daarentegen vaker eindigen met óf een hoger loon óf geen baan. Verder blijken studenten die veel belang hechten aan een hoge materiele beloning later in hun carrière meer te verdienen dan studenten die hier minder belang aan hechten (Hilmer \& Hilmer, 2012), al gaat dit ten koste van hun baantevredenheid (Mora et al., 2007). Daarentegen blijkt dat studenten die ontwikkelingsmogelijkheden in een baan belangrijk vinden later juist een hoge baantevredenheid kennen (Mora et al., 2007; Villa et al., 2007). 
Niet iedereen krijgt dezelfde karaktereigenschappen en beroepsidealen aangeleerd, en verschillen op basis van geslacht, sociale herkomst en migratieachtergrond zouden daarbij een rol kunnen spelen. Daarnaast kunnen mogelijke verschillen in risicobereidheid en baanvoorkeuren ontstaan wanneer afgestudeerden reflecteren op hun huidige baankansen en vooruitkijken naar de toekomst (Griffith, 1980; Turner \& Turner, 1995). Afhankelijk van hun achtergrondsituatie kunnen sommige (groepen) werkzoekenden vooral prioriteit geven aan de materiële kenmerken van een baan zoals het salaris, terwijl andere(n) (groepen) juist op zoek gaan naar een baan die nieuwe uitdagingen of ruimte voor verder leren biedt. Dergelijke voorkeuren kunnen verschillend uitpakken voor verschillende arbeidsmarktuitkomsten.

\section{De relatie tussen persoonlijkheidskenmerken/baanvoorkeuren en sociale herkomst}

Voorkeuren voor bepaalde typen banen ontwikkelen zich in de jeugd en worden daarbij beïnvloed door de sociale positie van de ouders (Johnson, 2002; Johnson \& Mortimer, 2011). Zo blijken jongeren van hoge sociale afkomst minder belang te hechten aan extrinsieke baankenmerken zoals een hoog inkomen (Johnson, 2002; Lindsay \& Knox, 1984; Johnson \& Mortimer, 2011; Wary et al, 2011), en meer aan intrinsieke baankenmerken (Lindsay \& Knox, 1984; Chaves, Ramos Santos, 2016). Deze verschillen zouden ontstaan doordat jongeren met hoogopgeleide ouders opgroeien in een context waarin iedereen genoeg verdient, terwijl jongeren met een lage sociale herkomst daarentegen opgroeien met het idee dat je moet werken ervoor te zorgen dat er voldoende geld op de plank ligt om rond te komen (Johnson \& Mortimer 2011; Hjort 2015).

Dergelijke verschillen tijdens de opvoeding zou ook leiden tot verschillen in de risicobereidheid die men vertoont in het zoeken naar een baan (Charles en Hurst, 2003; Hryshko, Luengo-Prado en Sorensen, 2011; Dohmen et al., 2011/2012). Het is daarom te verwachten dat: risicobereidheid, materiele ambitie, en behoefte aan uitdagingen op het werk gedeeltelijke verklaringen bieden voor de verschillen in arbeidsmarktuitkomsten tussen hbo-afgestudeerden met laagopgeleide ouders en hoogopgeleide ouders (H6a).

\section{De relatie tussen persoonlijkheidskenmerken/baanvoorkeuren en geslacht}

Johnson (2002) stelt dat houdingen ten aanzien van werk in belangrijke mate gevormd worden door historische ideeën over rolpatronen en mannen- en vrouwenberoepen. Mannen zijn relatief vaak gericht op inkomen, en in iets mindere mate op uitdaging, en vrouwen meer op de immateriële aspecten van een baan zoals afwisseling en de mogelijkheid tot leren van nieuwe dingen (Konrad et al., 2000). Dergelijke genderverschillen bestaan vaak al op jongere leeftijd, lang voor de daadwerkelijke keuze voor een baan (Hirschi 2010), en sluiten aan bij algemene rolpatronen en verhoudingen tussen mannen en vrouwen (Evans \& Diekman, 2009). Vrouwen zijn ook minder snel bereidt om risico's te nemen dan mannen (Croson \& Gneezy, 2009; Halek \& Eisenhauer, 2001; Hartog et al., 2002).

Flory, Leibbrandt en List (2010) tonen aan dat vrouwen niet alleen andere voorkeuren hebben maar ook daadwerkelijk op andere banen solliciteren, bijvoorbeeld banen 
waarbij het salaris onzeker is doordat het gekoppeld wordt aan prestaties op de werkvloer. Vrouwen solliciteren ook minder vaak bij bedrijven die relatief goed betalen (Card et al., 2016). Vrouwen onderhandelen minder vaak over arbeidsvoorwaarden dan mannen, en met minder succes (Card et al., 2016; Säve-Söderbergh, 2007). Wel betekenen hun baanvoorkeuren dat zij vaak een hogere baantevredenheid kennen dan mannen. We verwachten daarom dat: verschillen in risicobereidheid, materiele ambitie, en behoefte aan uitdagingen op het werk gedeeltelijke verklaringen bieden voor de verschillen in arbeidsmarktuitkomsten tussen mannelijke en vrouwelijke hbo-afgestudeerden (H6b).

\section{De relatie tussen persoonlijkheidskenmerken/baanvoorkeuren en migratieachtergrond}

Studenten met een migratieachtergrond laten zich in hun opleidingskeuze vaker leiden door extrinsieke motivaties, zoals salaris, en minder door intrinsieke motivatie (Jennissen \& Oudhof, 2007, p. 84; van Gent et al, 2006). Uit Amerikaans onderzoek blijkt dat ook bij het zoeken naar een (eerste) baan afgestudeerden met een migratieachtergrond relatief meer belang hechten aan inkomen, omdat zij vaker opgroeien in een omgeving met economische moeilijkheden (Johnson, 2002). Dit zou versterkt worden door de verwachting dat ze bij de eerste stappen op de arbeidsmarkt te maken zullen krijgen met een "ethnic penalty" (Luzzo \& McWhirter, 2001), en uit voorzorg meer prioriteit geven aan het veiligstellen van een baan en inkomen boven werkinhoud en uitdaging (Van Gent et al., 2006). Dit beeld wordt enigszins genuanceerd door Van Hooft en anderen (2004), die bij Turkse Nederlanders wel een hoog belang aan baanzekerheid constateerden, maar op andere materiële en immateriële baanmerken geen grote verschillen zagen ten opzichte van Nederlanders zonder migratieachtergrond. We verwachten daarom dat verschillen in materiele ambitie en belang aan uitdagingen die het werk biedt gedeeltelijke verklaringen bieden voor de verschillen in arbeidsmarktuitkomsten tussen hbo-afgestudeerden met migratieachtergrond en hbo-afgestudeerden zonder een migratie-achtergrond (H6c).

\subsubsection{Het belang van gezinsvorming en zorgtaken in de onderwijs-arbeidsmarkt transitie}

Tot slot is herhaaldelijk uit onderzoek gebleken dat vrouwen meer zorgtaken hebben dan mannen, en dat dit negatief gerelateerd is aan hun arbeidsmarktuitkomsten (Bertrand et al., 2010; Fortin, 2005). Een ander gevolg van dit groter aantal zorgtaken is dat vrouwen vaker in deeltijd werken dan mannen. Ook deeltijdwerk blijkt negatief gerelateerd te zijn aan arbeidsmarktuitkomsten (Bertrand et al., 2010; Fortin, 2005). We verwachten daarom dat: verschillen in zorgtaken en deeltijdwerk gedeeltelijke verklaringen bieden voor de verschillen in arbeidsmarktuitkomsten tussen mannen en vrouwen ( $\mathrm{H} 7)$. 


\section{Hypothesen}

$\mathrm{H}_{1}$ : Hbo-afgestudeerden met een lage sociale herkomst kennen gemiddeld een slechtere arbeidsmarktpositie dan hbo-afgestudeerden met een hoge sociale herkomst, zowel op korte als op middellange termijn.

$\mathrm{H}_{2}$ : Vrouwelijke hbo-afgestudeerden kennen gemiddeld een slechtere arbeidsmarktpositie dan mannelijke hbo-afgestudeerden, zowel op korte als op middellange termijn.

$\mathrm{H}_{3}$ : Hbo-afgestudeerden met een niet-westerse migratieachtergrond kennen gemiddeld een slechtere arbeidsmarktpositie dan hbo-afgestudeerden zonder een migratieachtergrond of met een westerse migratieachtergrond, zowel op korte als op middellange termijn.

$\mathrm{H}_{4}$ : Opleidingssector biedt een gedeeltelijke verklaring voor:

- de verschillen in arbeidsmarktuitkomsten tussen hbo-afgestudeerden met laagopgeleide ouders en hbo-afgestudeerden met hoogopgeleide ouders ( $\left.\mathrm{H}_{4} \mathrm{a}\right)$

- de verschillen in arbeidsmarktuitkomsten tussen vrouwelijke en mannelijke hboafgestudeerden $\left(\mathrm{H}_{4} \mathrm{~b}\right)$

- de verschillen in arbeidsmarktuitkomsten tussen hbo-afgestudeerden met een migratieachtergrond en hbo-afgestudeerden zonder migratieachtergrond $\left(\mathrm{H}_{4} \mathrm{C}\right)$

$\mathrm{H}_{5}$ : Sociaal kapitaal biedt een gedeeltelijke verklaring voor:

- de verschillen in arbeidsmarktuitkomsten tussen hbo-afgestudeerden met laagopgeleide ouders en hbo-afgestudeerden met hoogopgeleide ouders $\left(\mathrm{H}_{5} \mathrm{a}\right)$

- de verschillen in arbeidsmarktuitkomsten tussen vrouwelijke en mannelijke hboafgestudeerden $\left(\mathrm{H}_{5} \mathrm{~b}\right)$

- de verschillen in arbeidsmarktuitkomsten tussen hbo-afgestudeerden met een migratieachtergrond en hbo-afgestudeerden zonder migratieachtergrond $\left(\mathrm{H}_{5} \mathrm{C}\right)$

H6: Verschillen in baanvoorkeuren bieden een gedeeltelijke verklaringen voor:

- de verschillen in arbeidsmarktuitkomsten tussen hbo-afgestudeerden met laagopgeleide ouders en hbo-afgestudeerden met hoogopgeleide ouders ( $\mathrm{H} 6 \mathrm{a})$

- de verschillen in arbeidsmarktuitkomsten tussen vrouwelijke en mannelijke hboafgestudeerden $(\mathrm{H} 6 \mathrm{~b})$

- de verschillen in arbeidsmarktuitkomsten tussen hbo-afgestudeerden met een migratieachtergrond en hbo-afgestudeerden zonder migratieachtergrond $(\mathrm{H} 6 \mathrm{c})$

H7: Verschillen in zorgtaken en deeltijdwerk bieden een gedeeltelijke verklaring voor:

- de verschillen in arbeidsmarktuitkomsten tussen vrouwelijke en mannelijke hboafgestudeerden ( $\mathrm{H} 6 \mathrm{~b})$ 



\section{DATA EN METHODE}

\subsection{Data}

Voor het huidige onderzoek is gebruik gemaakt van twee metingen van de HBO-Monitor. De reguliere meting van de HBO-Monitor, die plaatst vindt één jaar na afstuderen, en de herhalingsmeting die vier tot acht jaar na afstuderen is afgenomen onder een deel van dezelfde groep. In het huidige onderzoek focussen we ons op de metingen van vier afstudeercohorten van hbo-bachelors uit 2007, 2009, 2010 en 2011. Deze afstudeercohorten zijn voor het eerst benaderd om deel te nemen aan de HBO-Monitor in respectievelijk 2008, 2009, 2011 en 2102 (één jaar na afstuderen). De herhalingsmeting heeft in 2015 plaatsgevonden, toen deze afgestudeerden zich reeds vier tot acht jaar op de arbeidsmarkt bevonden. De twee metingen (korte en middellange termijn) zijn op persoonsniveau aan elkaar gekoppeld, zodat het mogelijk is om de ontwikkeling op de arbeidsmarkt na de hbo-opleiding te bestuderen. Deze koppeling is uiteindelijk gemaakt aan de hand van e-mailadressen, achtergrondgegevens aangeleverd door de hogescholen en op basis van overeenkomsten in afstudeerjaar, school en opleiding. In totaal hebben $12,4 \%$ van de afgestudeerden in de eerste meting (korte termijn) ook meegedaan aan de tweede meting (middellange termijn). Van de herhalingsmeting is bijna $85 \%$ van de respondenten gekoppeld aan de eerste meting. De omvang van de responsgroep is zodoende 5,839 hbo-bachelors. Fluctuatie in het aantal respondenten per analyse is mogelijk, omdat afhankelijk van de arbeidsmarkt uitkomsten soms alleen werkenden worden meegenomen of van respondenten antwoorden ontbreken, bijvoorbeeld wanneer zij een vraag hebben overgeslagen. In de vragenlijsten zijn afgestudeerde hbo'ers onder andere bevraagd over hun behaalde opleiding(en), actuele arbeidsmarktpositie en persoonlijke kenmerken.

\subsection{Metingen}

\section{Arbeidsmarktuitkomsten}

De arbeidsmarktuitkomsten van de hbo-afgestudeerden zijn op beide meetmomenten gemeten aan de hand van de volgende indicatoren: (1) het al dan niet werkzaam zijn, (2) vaste versus tijdelijke aanstelling, (3) baan op minimaal hbo-niveau, (4) bruto uurloon en (5) baantevredenheid. ${ }^{.}$Deze uitkomsten zijn op beide meetmomenten gemeten.

1 Hbo-afgestudeerden die verder zijn gaan studeren worden hierbij niet meegenomen. Bij uurloon is de bovenste en onderste $1 \%$ verwijderd en is een inflatiecorrectie toegepast. Baantevredenheid is gemeten op een 5-punt Likertschaal lopend van zeer ontevreden (1) tot zeer tevreden (5). 


\section{Achtergrondkenmerken}

Om meer inzicht te krijgen in de achtergrondkenmerken van de afgestudeerden hebben we middels de eerste meting meer informatie vergaard over hun geslacht en migratieachtergrond, en middels de tweede meting over hun sociaaleconomische status (SES). Geslacht is ingedeeld in man en vrouw. De sociaaleconomische status is bepaald aan de hand van het opleidingsniveau van beide ouders. Wanneer het opleidingsniveau van beide ouders niet even hoog was, is gekozen voor het hoogste opleidingsniveau van de twee. Vervolgens is een onderscheid gemaakt tussen lage, middelhoge en hoge ouderlijke SES. Migratieachtergrond wordt bepaald aan de hand van de CBS-definities. Hierbij worden personen die zelf afkomstig zijn, of waarvan één van beide ouders afkomstig is uit Turkije of landen uit Afrika, Latijns-Amerika en Azië (exclusief Indonesië en Japan), beschouwt als personen met een niet-westerse migratieachtergrond. Bij westerse achtergrond gaat het om een afkomst uit een van de overige landen.

\section{Verklarende factoren}

Tot slot hebben we informatie vergaard over mogelijke verklarende factoren die arbeidsmarktverschillen tussen de deelpopulaties zouden kunnen verklaren, namelijk opleidingssector, baanvoorkeuren, risicobereidheid, sociaal kapitaal, het hebben van kinderen, het verrichten van zorgtaken en het werken in deeltijd. Opleidingssector was al voorafgaande aan beide metingen bekend als administratief gegeven. Deeltijd werk werd bij werkenden in beide metingen vastgesteld aan de hand van aantal gewerkte uren, waarbij 32 uren per week of minder als deeltijd werk wordt aangemerkt. Over het hebben van kinderen en het verrichten van zorgtaken voor kinderen en/of overige gezinsleden is gevraagd in de tweede meting, zowel met betrekking op het meetmoment zelf als retrospectief op het moment van de eerste meting.

De overige kenmerken zijn allemaal in de tweede meting gevraagd. De baanvoorkeuren van afgestudeerden zijn gemeten aan de hand van een reeks stellingen, waaruit twee schalen zijn geconstrueerd, te weten "Het openstaan voor nieuwe uitdagingen" en "Materiële ambitie" (zie bijlage A voor meer details van hoe deze schalen zijn gemaakt). Risicobereidheid is gemeten met de volgende vraag: In hoeverre bent $u$ iemand die bereid is om risico's te nemen? Respondenten konden vragen en stellingen beantwoorden op een 5-punt Likertschaal lopend van helemaal mee eens (1) tot helemaal niet mee eens (5). "Sociaal kapitaal" behelst drie stellingen die de nuttigheid van het sociale netwerk bij de zoektocht naar werk weergeven (zie bijlage A voor meer details). Bij al deze kenmerken wordt aangenomen dat ze relatief stabiel zijn in de tijd. Hoewel deze assumptie in letterlijke zin wellicht discutabel is, wordt in de onderzoeksliteratuur meestal gevonden dat veranderingen onder volwassenen hooguit zeer langzaam plaatsvinden (Anusic \& Schimmack, 2016).

\subsection{Beschrijvende statistieken van de drie deelpopulaties}

Zoals eerder als beschreven, staan in het huidige onderzoek drie deelpopulaties van afgestudeerde hbo-bachelors centraal: vrouwelijke afgestudeerden, afgestudeerden 
van lage sociaaleconomische herkomst en afgestudeerden met een migratieachtergrond. In tabel $3.1 \mathrm{t} / \mathrm{m} 3.3$ geven we de achtergrondkenmerken van deze deelpopulaties weer.

\subsubsection{Beschrijvende statistieken naar sociaaleconomische herkomst}

Uit tabel 3.1 blijkt allereerst dat afgestudeerden van lage sociaaleconomische herkomst op de korte termijn het op twee arbeidsmarktindicatoren (vast contract en fulltimebaan) iets beter doen dan hun tegenpolen met een middelhoge of hoge SES. Vier tot acht jaar na afstuderen is onder deze groep het aandeel met een fulltimebaan inmiddels vergelijkbaar met dat van afgestudeerden met een meer geprivilegieerde herkomst, maar hebben ze hun voorsprong in termen van vast werk weten te behouden. Daarnaast zijn afgestudeerden van lagere sociaaleconomische herkomst iets vaker werkzaam in de sector Sociale Studies, en hebben ze gemiddeld genomen vaker kinderen. Ze hebben tot slot het meest van de drie groepen behoefte materieel succes, het minst nuttige sociale netwerk en de laagste risicobereidheid.

Afgestudeerden van hoge sociaaleconomische herkomst hebben verder het vaakst een goede baanmatch op korte en middellange termijn. Op middellange termijn hebben ze het hoogste gemiddelde bruto uurloon. Ze studeren iets vaker dan afgestudeerden met een middelhoge of lage SES af in de sectoren gezondheidszorg en kunst. Ook hebben ze gemiddeld genomen iets meer behoefte aan nieuwe uitdagingen binnen een baan, het grootste sociale netwerk en de hoogste risicobereidheid.

\subsubsection{Beschrijvende statistieken naar geslacht}

Uit tabel 3.2 komt naar voren dat hoewel mannen en vrouwen bijna even vaak werkzaam zijn kort na afstuderen, vrouwen beduidend minder vaak een baan op hbo-niveau hebben, beduidend minder verdienen en beduidend minder vaak een vast contract of fulltimebaan hebben. Niet verwonderlijk zijn ze dan ook minder tevreden dan mannen met hun eerste werkervaringen. Helaas slagen vrouwen er niet in op middellange termijn de mannen bij te benen. Sterker nog: de verschillen in loon en het hebben van een fulltimebaan zijn vier tot acht jaar na afstuderen nog groter. De verschillen in het hebben van een vast contract en het hebben van een baan op hbo-niveau worden echter kleiner. Aangezien vrouwen het op middellange termijn nog steeds op iedere arbeidsmarktuitkomst minder goed doen dan mannen, is het niet verwonderlijk dat hun baantevredenheid beduidend lager blijft dan die van mannen. Verder valt op dat vrouwen vaker afstuderen in de sectoren Onderwijs, Gezondheidszorg en Sociale Studies dan mannen. Mannen zijn daarentegen studeren vaker af in de sectoren Bètatechniek en Economie. Mannen hechten meer waarde aan materieel succes, en zijn meer bereid risico's te nemen. Er is een zeer groot verschil in het aantal uren dat mannen en vrouwen gemiddeld besteden aan zorgtaken voor kinderen en/of andere familieleden. Vrouwen besteden hieraan twee keer zoveel tijd dan mannen. 
TABEL 3.1 Beschrijvende statistieken naar ouderlijke achtergrond

\begin{tabular}{|c|c|c|c|}
\hline & Lage SES & Middenhoge SES & Hoge SES \\
\hline \multicolumn{4}{|l|}{ Arbeidmarktuitkomsten (korte termijn) } \\
\hline Werkzaam & $96,4 \%$ & $95,7 \%$ & $95,4 \%$ \\
\hline Vast contract & $50,8 \%$ & $47,3 \%$ & $47,6 \%$ \\
\hline Baanmatch & $78,8 \%$ & $78,2 \%$ & $80,5 \%$ \\
\hline Bruto uurloon & 14,36 & 14,25 & 14,26 \\
\hline Baantevredenheid & 3,78 & 3,77 & 3,75 \\
\hline Full-time baan & $64,5 \%$ & $61,5 \%$ & $61,7 \%$ \\
\hline \multicolumn{4}{|c|}{ Arbeidmarktuitkomsten (Middellange termijn) } \\
\hline Werkzaam & $96,2 \%$ & $97,4 \%$ & $96,6 \%$ \\
\hline Vast contract & $82,9 \%$ & $80,0 \%$ & $80,0 \%$ \\
\hline Baanmatch & $83,2 \%$ & $82,9 \%$ & $85,9 \%$ \\
\hline Bruto uurloon & 17,08 & 17,00 & 17,35 \\
\hline Baantevredenheid & 3,67 & 3,68 & 3,68 \\
\hline Full-time baan & $63,3 \%$ & $63,2 \%$ & $63,9 \%$ \\
\hline Vrouw & $56,9 \%$ & $59,2 \%$ & $57,4 \%$ \\
\hline \multicolumn{4}{|l|}{ Migratieachtergrond } \\
\hline Nederlands & $85,8 \%$ & $91,6 \%$ & $88,7 \%$ \\
\hline Westerse achtergrond & $4,9 \%$ & $5,4 \%$ & $8,1 \%$ \\
\hline Niet-westerse achtergrond & $9,3 \%$ & $3,0 \%$ & $3,2 \%$ \\
\hline \multicolumn{4}{|l|}{ Sector } \\
\hline Economie & $31,8 \%$ & $29,8 \%$ & $30,4 \%$ \\
\hline Onderwijs & $12,6 \%$ & $12,7 \%$ & $11,5 \%$ \\
\hline Bètatechniek en agro \& food & $20,5 \%$ & $23,1 \%$ & $19,2 \%$ \\
\hline Gezondheidszorg & $13,8 \%$ & $14,0 \%$ & $15,0 \%$ \\
\hline Sociale Studies & $16,6 \%$ & $15,2 \%$ & $14,2 \%$ \\
\hline Kunst & $4,7 \%$ & $5,2 \%$ & $9,7 \%$ \\
\hline \multicolumn{4}{|l|}{ Baanvoorkeuren } \\
\hline Nieuwe uitdagingen & 4,14 & 4,16 & 4,22 \\
\hline Materiële ambitie & 3,41 & 3,36 & 3,36 \\
\hline Risicobereidheid & 3,27 & 3,32 & 3,36 \\
\hline Sociaal netwerk & 3,41 & 3,50 & 3,61 \\
\hline \multicolumn{4}{|l|}{ Gezinsvorming en zorg (korte termijn) } \\
\hline Kinderen & $4,3 \%$ & $2,4 \%$ & $2,7 \%$ \\
\hline Zorg voor kinderen/overige gezinsleden & $5,2 \%$ & $5,6 \%$ & $4,8 \%$ \\
\hline Zo ja: gemiddelde uren p.w. & 27,35 & 30,72 & 35,35 \\
\hline \multicolumn{4}{|c|}{ Gezinsvorming en zorg (middellange termijn) } \\
\hline 1 kind & $18,3 \%$ & $15,5 \%$ & $13,6 \%$ \\
\hline 2 of meer kinderen & $12,5 \%$ & $11,4 \%$ & $11,1 \%$ \\
\hline Zorg voor kinderen/overige gezinsleden & $28,9 \%$ & $27,9 \%$ & $25,4 \%$ \\
\hline Zo ja: gemiddelde uren p.w. & 35,21 & 35,63 & 32,62 \\
\hline
\end{tabular}

Data: HBO-Monitor 
TABEL 3.2 Beschrijvende statistieken naar geslacht

\begin{tabular}{|c|c|c|}
\hline & Man & Vrouw \\
\hline \multicolumn{3}{|l|}{ Arbeidmarktuitkomsten (korte termijn) } \\
\hline Werkzaam & $95,9 \%$ & $95,6 \%$ \\
\hline Vast contract & $56,2 \%$ & $42,7 \%$ \\
\hline Baanmatch & $84,7 \%$ & $75,5 \%$ \\
\hline Bruto uurloon & 14,69 & 13,92 \\
\hline Baantevredenheid & 3,83 & 3,71 \\
\hline Full-time baan & $79,7 \%$ & $49,5 \%$ \\
\hline \multicolumn{3}{|c|}{ Arbeidmarktuitkomsten (Middellange termijn) } \\
\hline Werkzaam & $97,8 \%$ & $96,6 \%$ \\
\hline Vast contract & $84,2 \%$ & $78,2 \%$ \\
\hline Baanmatch & $89,1 \%$ & $81,2 \%$ \\
\hline Bruto uurloon & 18,39 & 16,26 \\
\hline Baantevredenheid & 3,71 & 3,65 \\
\hline Full-time baan & $86,0 \%$ & $47,0 \%$ \\
\hline \multicolumn{3}{|l|}{ Ouderlijke SES } \\
\hline Laag & $21,1 \%$ & $20,4 \%$ \\
\hline Middenhoog & $27,9 \%$ & $29,5 \%$ \\
\hline Hoog & $51,0 \%$ & $50,1 \%$ \\
\hline \multicolumn{3}{|l|}{ Migratieachtergrond } \\
\hline Nederlands & $88,3 \%$ & $88,9 \%$ \\
\hline Westerse achtergrond & $6,7 \%$ & $6,7 \%$ \\
\hline Niet-westerse achtergrond & $5,0 \%$ & $4,4 \%$ \\
\hline \multicolumn{3}{|l|}{ Sector } \\
\hline Economie & $37,7 \%$ & $25,9 \%$ \\
\hline Onderwijs & $7,1 \%$ & $16,1 \%$ \\
\hline Bètatechniek en agro \& food & $37,5 \%$ & $7,4 \%$ \\
\hline Gezondheidszorg & $5,1 \%$ & $21,1 \%$ \\
\hline Sociale Studies & $4,7 \%$ & $22,1 \%$ \\
\hline Kunst & $7,9 \%$ & $7,5 \%$ \\
\hline \multicolumn{3}{|l|}{ Baanvoorkeuren } \\
\hline Nieuwe uitdagingen & 4,20 & 4,18 \\
\hline Materiële ambitie & 3,47 & 3,31 \\
\hline Risicobereidheid & 3,43 & 3,25 \\
\hline Sociaal netwerk & 3,48 & 3,47 \\
\hline \multicolumn{3}{|l|}{ Gezinsvorming en zorg (korte termijn) } \\
\hline Kinderen & $2,7 \%$ & $3,1 \%$ \\
\hline Zorg voor kinderen/overige gezinsleden & $5,2 \%$ & $5,1 \%$ \\
\hline Zo ja: gemiddelde uren p.w. & 20,81 & 40,73 \\
\hline \multicolumn{3}{|c|}{ Gezinsvorming en zorg (middellange termijn) } \\
\hline 1 kind & $14,1 \%$ & $15,9 \%$ \\
\hline 2 of meer kinderen & $11,7 \%$ & $11,1 \%$ \\
\hline Zorg voor kinderen/overige gezinsleden & $24,0 \%$ & $28,9 \%$ \\
\hline Zo ja: gemiddelde uren p.w. & 21,19 & 42,33 \\
\hline
\end{tabular}

Data: HBO-Monitor 


\subsubsection{Beschrijvende statistieken naar migratieachtergrond}

Tabel 3.3 toont tot slot arbeidsmarktverschillen naar migratieachtergrond. Allereerst is te zien dat afgestudeerden met vooral een niet-westerse migratieachtergrond minder vaak een baan hebben één jaar naar afstuderen dan afgestudeerden met een Nederlandse achtergrond. Opvallend is dat afgestudeerden met een Nederlandse achtergrond kort na afstuderen het minst vaak een fulltimebaan hebben. Ze kennen wel één jaar na afstuderen de hoogste baantevredenheid. Afgestudeerden met een niet-westerse achtergrond hebben op dat moment het hoogste gemiddelde bruto uurloon.

Vier tot acht jaar na afstuderen kampen hbo-bachelors met een niet-westerse achtergrond nog steeds met een achterstand op het gebeid van het hebben van een baan, en zijn zij nog steeds iets minder tevreden met de banen die ze hebben. Hbo-bachelors met een westerse achtgrond hebben vier tot acht jaar na afstuderen het hoogste gemiddelde bruto uurloon.

Niet-westerse afgestudeerden kennen vaak een lage ouderlijke SES, en studeren vaak af in de sectoren Economie en Sociale Studies. Hbo-bachelors met een Nederlandse achtergrond oververtegenwoordigd zijn in de sectoren Bètatechniek en Agro \& Food en Onderwijs, terwijl hbo-bachelors met een westerse achtgrond oververtegenwoordigd zijn in de sector Kunst. Op het gebied van baanvoorkeuren blijkt verder dat hbobachelors met een migratieachtergrond beduidend meer behoefte hebben aan nieuwe uitdagingen op het werk en een grotere risicobereidheid en materiele ambitie kennen dan hbo-bachelors met een Nederlandse achtergrond. Vooral niet-westerse afgestudeerden hebben relatief weinig aan hun sociale netwerk. Tot slot hebben hbo-bachelors met een migratieachtergrond meer kinderen en meer zorgtaken dan hbo-bachelors met een Nederlandse achtergrond 
TABEL 3.3 Beschrijvende statistieken naar migratieachtergrond

\begin{tabular}{|c|c|c|c|}
\hline & $\begin{array}{l}\text { Nederlandse } \\
\text { achtergrond }\end{array}$ & $\begin{array}{l}\text { Westerse } \\
\text { achtergrond }\end{array}$ & $\begin{array}{l}\text { Niet-westerse } \\
\text { achtergrond }\end{array}$ \\
\hline \multicolumn{4}{|l|}{ Arbeidmarktuitkomsten (korte termijn) } \\
\hline Werkzaam & $96,1 \%$ & $94,1 \%$ & $90,7 \%$ \\
\hline Vast contract & $48,2 \%$ & $54,3 \%$ & $45,4 \%$ \\
\hline Baanmatch & $79,3 \%$ & $81,4 \%$ & $78,5 \%$ \\
\hline Bruto uurloon & 14,23 & 14,23 & 14,67 \\
\hline Baantevredenheid & 3,78 & 3,69 & 3,54 \\
\hline Full-time baan & $61,7 \%$ & $66,3 \%$ & $64,7 \%$ \\
\hline \multicolumn{4}{|c|}{ Arbeidmarktuitkomsten (Middellange termijn) } \\
\hline Werkzaam & $97,5 \%$ & $94,6 \%$ & $93,0 \%$ \\
\hline Vast contract & $81,0 \%$ & $80,5 \%$ & $78,0 \%$ \\
\hline Baanmatch & $84,7 \%$ & $82,3 \%$ & $86,3 \%$ \\
\hline Bruto uurloon & 17,08 & 18,31 & 17,36 \\
\hline Baantevredenheid & 3,68 & 3,66 & 3,59 \\
\hline Full-time baan & $63,3 \%$ & $62,5 \%$ & $64,7 \%$ \\
\hline \multicolumn{4}{|l|}{ Ouderlijke SES } \\
\hline Laag & $20,0 \%$ & $15,2 \%$ & $43,6 \%$ \\
\hline Middenhoog & $29,7 \%$ & $23,4 \%$ & $19,7 \%$ \\
\hline Hoog & $50,3 \%$ & $61,4 \%$ & $36,7 \%$ \\
\hline Vrouw & $58,0 \%$ & $57,8 \%$ & $55,5 \%$ \\
\hline \multicolumn{4}{|l|}{ Sector } \\
\hline Economie & $29,2 \%$ & $38,8 \%$ & $45,6 \%$ \\
\hline Onderwijs & $13,0 \%$ & $6,2 \%$ & $8,1 \%$ \\
\hline Bètatechniek en agro \& food & $20,8 \%$ & $12,4 \%$ & $15,6 \%$ \\
\hline Gezondheidszorg & $15,0 \%$ & $14,0 \%$ & $5,2 \%$ \\
\hline Sociale Studies & $14,7 \%$ & $14,2 \%$ & $19,3 \%$ \\
\hline Kunst & $7,3 \%$ & $14,5 \%$ & $6,3 \%$ \\
\hline \multicolumn{4}{|l|}{ Baanvoorkeuren } \\
\hline Nieuwe uitdagingen & 4,17 & 4,27 & 4,33 \\
\hline Materiële ambitie & 3,35 & 3,47 & 3,76 \\
\hline Risicobereidheid & 3,31 & 3,41 & 3,43 \\
\hline Sociaal netwerk & 3,48 & 3,56 & 3,34 \\
\hline \multicolumn{4}{|l|}{ Gezinsvorming en zorg (korte termijn) } \\
\hline Kinderen & $2,8 \%$ & $3,9 \%$ & $4,5 \%$ \\
\hline Zorg voor kinderen/overige gezinsleden & $4,6 \%$ & $8,1 \%$ & $11,6 \%$ \\
\hline Zo ja: gemiddelde uren p.w. & 29,86 & 36,32 & 47,55 \\
\hline \multicolumn{4}{|c|}{ Gezinsvorming en zorg (middellange termijn) } \\
\hline 1 kind & $14,9 \%$ & $15,5 \%$ & $20,3 \%$ \\
\hline 2 of meer kinderen & $11,0 \%$ & $13,7 \%$ & $17,1 \%$ \\
\hline Zorg voor kinderen/overige gezinsleden & $26,6 \%$ & $27,4 \%$ & $33,5 \%$ \\
\hline Zo ja: gemiddelde uren p.w. & 33,89 & 36,86 & 34,29 \\
\hline
\end{tabular}

Data: HBO-Monitor 



\section{RESULTATEN}

\subsection{Nadere analyse van de invloed van achtergrondkenmerken}

In voorgaand hoofdstuk hebben we onderzocht hoe de achtergrondkenmerken gerelateerd zijn aan zowel de arbeidsmarktuitkomsten als verklarende factoren. Hoewel deze verschillen een eerste beeld geven, wordt er in deze analyses geen rekening gehouden met andere kenmerken die mogelijk van invloed zijn op de uitkomsten, zoals afstudeercijfer, leeftijd, vooropleiding en afstudeercohort. In dit hoofdstuk is de invloed van achtergrondkenmerken nogmaals bestudeerd, rekening houdend met deze kenmerken. Er wordt tevens bekeken in hoeverre de waargenomen verschillen statistisch significant zijn, en in hoeverre deze kunnen worden toegeschreven aan de zogenaamde verklarende factoren: verschillen in opleidingskeuze, sociaal kapitaal, baanvoorkeuren, gezinsvorming, zorgtaken en (bij baankenmerken) het werken in deeltijd. De arbeidsmarktuitkomsten worden apart bestudeerd op beide meetmomenten. Bij de middellange termijn uitkomsten zal ook worden gekeken naar de mate waarin effecten al worden verklaard door de arbeidsmarktsituatie op de korte termijn. De gepresenteerde percentages betreffen zogenaamde marginale effecten. Marginale effecten laten voor de verschillende deelpopulaties de procentuele toe- of afname in de kans op een bepaalde arbeidsmarktuitkomst zien ten opzichte van de referentiepopulatie.

We beginnen in paragraaf 4.1.1 met de effecten van ouderlijk herkomst. Hierbij wordt het relatieve effect van een middelhoge of een hoge sociaaleconomische status (SES) berekend ten opzichte van de referentiegroep, namelijk afgestudeerden met een lage SES. Paragraaf 4.1.2 toont de vergelijkbare resultaten voor geslacht (vrouwen ten opzichte van mannen) en paragraaf 4.1.3 de resultaten voor westerse en niet-westerse migratieachtergrond ten opzichte van afgestudeerden met een Nederlandse achtergrond.

Wat de verklarende factoren betreft wordt eerst gekeken naar de mate waarin deze gezamenlijk in staat zijn om eventuele verschillen in arbeidsmarktuitkomsten weg verklaren. Vervolgens wordt nagegaan in hoeverre iedere afzonderlijke verklarende factor apart de verschillen tussen de deelpopulaties kan verklaren.

\subsubsection{Ouderlijke afkomst}

Uit tabel 4.1 blijk dat ouderlijke afkomst erg weinig uitmaakt waar het om de arbeidsmarktuitkomsten van hbo-afgestudeerden gaat. Dit geldt zowel op de korte als de 
middellange termijn. De paar verschillen die in enige mate significant zijn, laten zelfs een licht nadeel zien voor afgestudeerden met een hoge SES ten opzichte van afgestudeerden met een lage SES. Op korte termijn blijken afgestudeerden met minstens één hoogopgeleide ouder, een iets lagere kans op werk te hebben, en op middellange termijn een iets lagere kans op een vaste baan. De effecten zijn slechts significant op $10 \%$ niveau, en zijn daarom mogelijk toe te schrijven aan toevallige variantie in de data. Alles bij elkaar kan onze eerste hypothese, dat sociale herkomst nog steeds positief is gerelateerd aan de arbeidsmarktpositie onder hbo-afgestudeerden, zowel op korte als op middellange termijn, niet door onze analyses worden bevestigd.

TABEL 4.1 Marginale effecten van sociale herkomst op arbeidsmarktuitkomsten

\begin{tabular}{|c|c|c|c|c|}
\hline & Kort & ermijn & Middella & Ige termijn \\
\hline & Zonder mediatoren & Incl. mediatoren & Zonder mediatoren & Incl. mediatoren \\
\hline Kans op werk (ref.: lage & & & & \\
\hline$(N=5839)$ & & & & \\
\hline - Middenhoge SES & $-0,96 \%$ & $-0,97 \%$ & $0,55 \%$ & $0,49 \%$ \\
\hline - HoogSES & $-1,39 \% *$ & $-1,41 \% *$ & $-0,03 \%$ & $-0,06 \%$ \\
\hline Vast contract (ref.: lage & & & & \\
\hline$(\mathrm{N}=4630)$ & & & & \\
\hline - Middelhoge SES & $-2,46 \%$ & $-2,19 \%$ & $-2,53 \%$ & $-1,86 \%$ \\
\hline - Hoog SES & $-3,25 \%$ & $-3,07 \%$ & $-3,14 \% *$ & $-2,08 \%$ \\
\hline Baanmatch (ref.: lage $S$ & & & & \\
\hline$(\mathrm{N}=5281)$ & & & & \\
\hline - Middenhoge SES & $-0,31 \%$ & $-0,69 \%$ & $0,12 \%$ & $-0,32 \%$ \\
\hline - Hoog SES & $1,04 \%$ & $0,93 \%$ & $2,24 \%$ & $1,08 \%$ \\
\hline Uurloon (ref.: lage SES) & & & & \\
\hline$(\mathrm{N}=4346)$ & & & & \\
\hline - Midden & $0,19 \%$ & $0,34 \%$ & $1,73 \%$ & $1,46 \%$ \\
\hline - Hoog & $0,24 \%$ & $0,85 \%$ & $0,33 \%$ & $-1,42 \%$ \\
\hline Baantevredenheid (ref. & & & & \\
\hline$(\mathrm{N}=* * * *)$ & & & & \\
\hline - Midden & $-1,65 \%$ & $-1,79 \%$ & $-0,54 \%$ & $-1,03 \%$ \\
\hline - Hoog & $-2,67 \%$ & $-2,98 \%$ & $-0,15 \%$ & $-0,79 \%$ \\
\hline
\end{tabular}

Noot ${ }^{* *}=$ Statisch significant bij een alfa van $0,01,{ }^{* *}=$ Statistisch significant bij een alfa van 0,05 *=Statistisch significant bij een alfa van 0,10. Gecontroleerd voor vooropleiding, afstudeercijfer, leeftijd en afstudeercohort.

Het blijkt dus dat sociale herkomst geen rol van betekenis heeft bij het bepalen van arbeidsmarktuitkomsten van hbo-afgestudeerden. Dit betekent niet per se dat sociale herkomst er niet toedoet op de Nederlandse arbeidsmarkt. Uit schoolverlatersdata van mbo-, havo- en vwo-schoolverlaters blijkt immers dat sociale herkomst wel degelijk een rol speelt bij de keuze om door te stromen naar vervolgonderwijs, en bij het bepalen 
van het niveau van de eventuele vervolgstudie (ROA, 2016). Echter, als jongeren eenmaal voor een hbo-opleiding hebben gekozen en deze succesvol hebben afgerond, blijken ze zich daarmee effectief te hebben losgemaakt van een eventueel nadeel op de arbeidsmarkt.

Omdat er geen noemenswaardige effecten zijn vastgesteld van sociale herkomst op arbeidsmarktuitkomsten, zien we af van een nadere analyse van de rol van de verklarende factoren. Door het verwerpen van hypothese 1 kunnen hypothesen $\mathrm{H}_{4} \mathrm{a}, \mathrm{H}_{5} \mathrm{a}$ en $\mathrm{H6a}$, waarin werd gesteld dat opleidingssector, sociaal kapitaal en baanvoorkeuren een gedeeltelijke verklaring voor de verschillen in arbeidsmarktuitkomsten tussen hbo-afgestudeerden met laagopgeleide ouders en hbo-afgestudeerden met hoogopgeleide ouders, niet worden getoetst.

\subsubsection{Geslacht}

Uit tabel 4.2 blijkt dat er wel forse verschillen zijn tussen mannen en vrouwen in arbeidsmarktuitkomsten op korte termijn (één jaar na afstuderen), en dat deze vaak heel hardnekkig zijn op de middellange termijn (vier tot acht jaar na afstuderen). Zo blijkt sprake te zijn van een klein maar niet significant verschil in de kans op werk op korte termijn, zich vier tot acht jaar na afstuderen te hebben uitgegroeid tot een significant verschil in baankansen van ruim één procentpunt. Onder werkzame afgestudeerden zijn daarnaast ook de beloningsverschillen tussen mannen en vrouwen gegroeid, van een $5 \%$ per uur loonnadeel één na afstuderen tot maar liefst een 12\% achterstand vier tot acht jaar na afstuderen. Wanneer we hierbij ook rekening houden met de grote en groeiende kloof tussen mannen en vrouwen in gewerkte uren (zie tabel 3.2), wordt het verschil in termen van "take-home pay" nog veel groter. Vrouwen halen verder slechts een klein deel van hun oorspronkelijke achterstand in termen van baanmatch in, van ongeveer 10 procentpunten kort na afstuderen tot ruim 8 procentpunten op middellange termijn. Alleen op het gebied van werkzekerheid en baantevredenheid blijken vrouwen een substantieel deel van hun initiële achterstand vier tot acht jaar na afstuderen te hebben ingehaald, maar ook hier blijven forse verschillen bestaan. Alles bij elkaar kunnen we daarom stellen dat onze hypothese 2 , dat vrouwelijke hbo-afgestudeerden gemiddeld een slechtere arbeidsmarktpositie kennen dan mannelijke hbo-afgestudeerden, zowel op korte als op middellange termijn, door de hier gepresenteerd analyses sterk wordt bevestigd.

Met betrekking tot de rol van de verklarende factoren bij het verklaren van verschillen tussen mannen en vrouwen komt een gemengd beeld naar voren. Op korte termijn lijken de verklarende factoren meestal nauwelijks wat uit te maken, met uitzondering van het effect van geslacht op baanmatch, dat zakt van bijna 10 procentpunten naar ruim 5 procentpunten, waarmee ruim $45 \%$ van het totaaleffect aan de verklarende factoren toe te schrijven is. Opvallend is het feit dat de korte termijn beloningsverschillen tussen mannen en vrouwen groter zijn dan op basis van hun opleidingskeuze, sociaal kapitaal, baanvoorkeuren, gezinsvorming, zorgtaken en gewerkte uren zou worden verwacht. 
TABEL 4.2 Marginale effecten van geslacht op arbeidsmarktuitkomsten

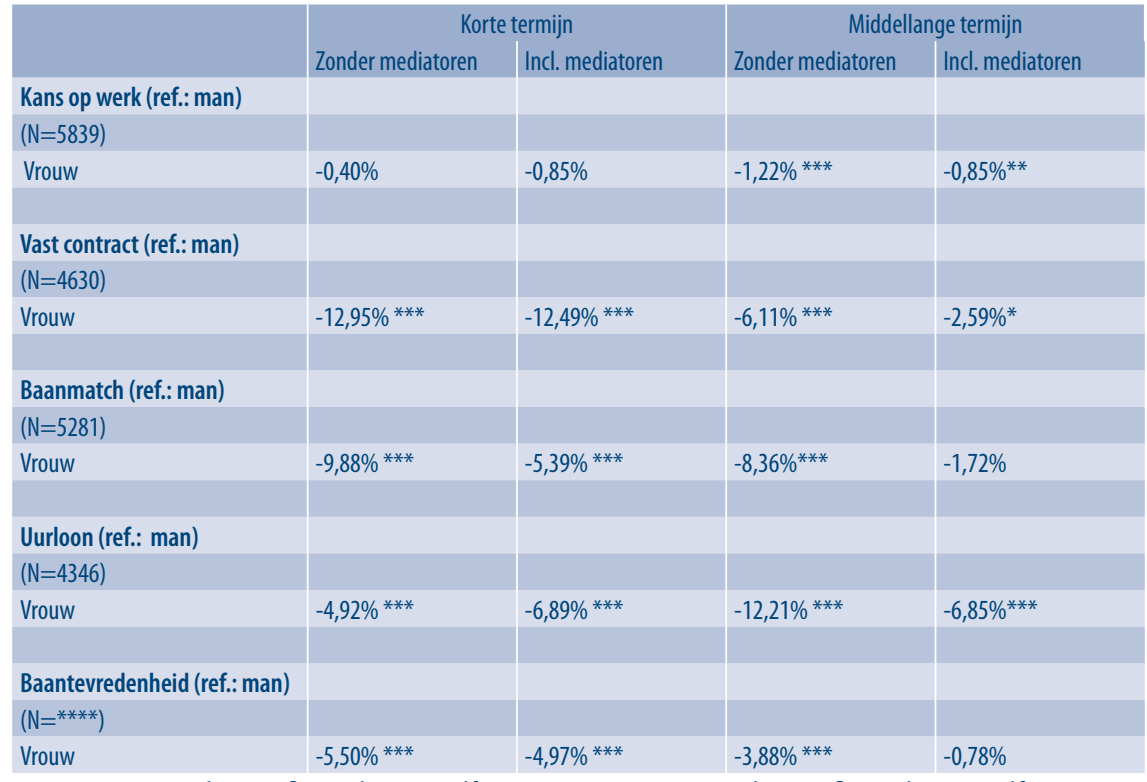

Noot ${ }^{* * *}=$ Statisch significant bij een alfa van $0,01,{ }^{* *}=$ Statistisch significant bij een alfa van 0,05 *=Statistisch significant bij een alfa van 0,10 . Gecontroleerd voor vooropleiding, afstudeercijfer, leeftijd en afstudeercohort.

Wat de effecten op middellange termijn betreft, is de rol van de verklarende factoren duidelijker en consistenter. Bij alle uitkomsten wordt een fors deel van het effect van geslacht hierdoor weg verklaard, en in het geval van baanmatch en baantevredenheid blijft er zelfs geen significant effect meer over.

\subsubsection{Migratieachtergrond}

In tabel 4.3 staan de marginale effecten van migratieachtergrond op arbeidsmarktuitkomsten. De effecten hiervan zijn minder geprononceerd en minder eenduidig dan die van geslacht, maar uit de tabel kan wel de conclusie worden getrokken dat met name hbo'ers met een niet-westerse achtergrond zowel op de korte als de middellange termijn een minder gunstige positie innemen op de arbeidsmarkt dan hbo'ers met een Nederlandse achtergrond. Het belangrijkste verschil is hun veel lagere kans op werk op zowel korte als middellange termijn. Interessant genoeg zijn er geen significante verschillen in objectieve baankenmerken onder die afgestudeerden die wel een baan hebben weten te bemachtigen. Hoewel niet-westerse afgestudeerden meer moeite lijken te hebben om werk te krijgen, hebben ze als ze eenmaal een baan hebben, ze net zo vaak een vaste aanstelling op minimaal hbo-niveau en verdienen ze net zoveel als afgestudeerden met een Nederlandse achtergrond. Wel blijken ze minder vaak tevreden te zijn met hun banen, vooral op korte termijn. 
TABEL 4.3 Marginale effecten van migratieachtergrond op arbeidsmarktuitkomsten

\begin{tabular}{|c|c|c|c|c|}
\hline & \multicolumn{2}{|c|}{ Korte termijn } & \multicolumn{2}{|c|}{ Middellange termijn } \\
\hline & Zonder mediatoren & Incl. mediatoren & Zonder mediatoren & Incl. mediatoren \\
\hline \multicolumn{5}{|c|}{ Kans op werk (ref.: NL achtergr.) } \\
\hline \multicolumn{5}{|c|}{$(\mathrm{N}=5839)$} \\
\hline Westerse achtergrond & $-1,54 \% *$ & $-1,26 \%$ & $-1,56 \%$ *** & $-1,18 \% * *$ \\
\hline Niet-westerse achtergrond & $-3,38 \% * * *$ & $-2,95 \% * * *$ & $-2,31 \% * * *$ & $-1,60 \% * * *$ \\
\hline \multicolumn{5}{|c|}{ Vast contract (ref.: NL achtergr.) } \\
\hline \multicolumn{5}{|l|}{$(\mathrm{N}=4630)$} \\
\hline Westerse achtergrond & $3,65 \%$ & $3,45 \%$ & $-1,58 \%$ & $-0,64 \%$ \\
\hline Niet-westerse achtergrond & $-3,84 \%$ & $-3,55 \%$ & $-2,69 \%$ & $-1,10 \%$ \\
\hline \multicolumn{5}{|l|}{ Baanmatch (ref.: NL achtergr.) } \\
\hline \multicolumn{5}{|l|}{$(\mathrm{N}=5281)$} \\
\hline Westerse achtergrond & $1,08 \%$ & $2,32 \%$ & $-3,08 \%$ & $-3,22 \% *$ \\
\hline Niet-westerse achtergrond & $-0,07 \%$ & $1,57 \%$ & $2,73 \%$ & $2,30 \%$ \\
\hline \multicolumn{5}{|l|}{ Uurloon (ref.: NL achtergr.) } \\
\hline \multicolumn{5}{|l|}{$(\mathrm{N}=4346)$} \\
\hline Westerse achtergrond & $-1,32 \%$ & $-1,22 \%$ & $4,97 \% * * *$ & $5,38 \% * * *$ \\
\hline Niet-westerse achtergrond & $1,54 \%$ & $1,33 \%$ & $0,96 \%$ & $-1,12 \%$ \\
\hline \multicolumn{5}{|l|}{$\begin{array}{l}\text { Baantevredenheid (ref.: NL } \\
\text { achtergr.) }\end{array}$} \\
\hline \multicolumn{5}{|l|}{$\left(\mathrm{N}={ }^{* * * *}\right)$} \\
\hline Westerse achtergrond & $-3,55 \%$ & $-2,41 \%$ & $-3,22 \%$ & $-2,90 \%$ \\
\hline Niet-westerse achtergrond & $-8,76 \% * *$ & $-6,09 \% *$ & $-6,93 \% *$ & $-4,15 \%$ \\
\hline
\end{tabular}

Noot ${ }^{* * *}=$ Statisch significant bij een alfa van $0,01,{ }^{* *}=$ Statistisch significant bij een alfa van 0,05 *=Statistisch significant bij een alfa van 0,10. Gecontroleerd voor vooropleiding, afstudeercijfer, leeftijd en afstudeercohort.

Afgestudeerden met een westerse migratieachtergrond hebben op korte en met name ook op middellange termijn ook wat meer moeite met het vinden van werk dan afgestudeerden zonder migratieachtergrond, als zijn de effecten minder sterk dan bij niet-westerse afgestudeerden. Opvallend is dat ze op de lange termijn juist 5\% meer verdienen dan Nederlandse afgestudeerden. Anders dan afgestudeerden met een nietwesterse migratieachtergrond, zijn ze niet minder tevreden met hun banen dan afgestudeerden met een Nederlandse achtergrond.

Net als bij geslacht blijken de verklarende factoren soms wel en soms geen rol te spelen bij het verklaren van effecten van migratieachtergrond. Een deel van het effect van migratieachtergrond op kans op werk wordt door de verklarende factoren weg verklaard, evenals een deel van het effect van een niet-westerse migratieachtergrond op baantevredenheid. Hierdoor is na controle voor de verklarende factoren dit laatste effect op middellange termijn niet significant meer. 


\subsection{De rol van de afzonderlijke verklarende factoren}

Het is belangrijk om meer te weten te komen over de rol die specifieke verklarende factoren afzonderlijk spelen bij het verklaren van verschillen tussen mannen en vrouwen en tussen afgestudeerden met en zonder migratieachtergrond. Tabellen 4.4 en 4.5 geven een overzicht van de effecten van de verklarende factoren afzonderlijk op alle arbeidsmarktuitkomsten op korte en middellange termijn. Uit de tabellen blijkt dat alle verklarende factoren effecten hebben op minstens één aspect of de korte en/of middellange termijn, maar dat er grote verschillen zijn in zowel het aantal arbeidsmarktuitkomsten waar ze effect op hebben als de sterkte van de effecten. Verschillen in opleidingssector tussen mannen en vrouwen blijkt een sterk voorspeller van arbeidsmarktuitkomsten te zijn, waarbij op korte termijn de sector Gezondheidszorg uitspringt met een sterk positief effect op alle uitkomsten in vergelijking met de referentiesector Economie. Op middellange termijn blijkt het beeld veel gedifferentieerder, maar ook hier blijkt het voor de uitkomsten afzonderlijk veel uit te maken in welke sector men is afgestudeerd.

Naast opleidingssector blijkt op de middellange termijn ook de arbeidsmarktsituatie op de korte termijn een sterke rol te spelen. Dit is niet echt verassend, maar is toch belangrijk in termen van consequenties: een goede baan kort na afstuderen is een sterke voorspeller van de kans op werk en de baankwaliteit later in de carrière. Verder blijkt een deeltijdaanstelling zowel op korte als middellange termijn sterk negatief samen te hangen met de kans op een vaste aanstelling, een goede baanmatch, en tevredenheid van de baan. Er blijkt echter geen straf te zitten op een deeltijdaanstelling in termen van uurloon, hoewel zoals hierboven al is opgemerkt, minder uren werken voor hetzelfde salaris per definitie een lager maandloon betekent.

De effecten van de overige verklarende factoren is vrij zwak en vaak beperkt tot enkele uitkomsten. Bij de baanvoorkeuren zijn de sterkste effecten te zien op middellange termijn, waar een hoge mate van ambitie gepaard gaat met een hogere beloning. Dit gaat echter ten koste van een lagere baantevredenheid. Sociale netwerken lijken alleen op de middellange termijn een rol van betekenis te hebben voor baantevredenheid, en in veel mindere mate het vinden van een baan met een goede match met de gevolgde opleiding. Een soortgelijk patroon zien we bij risicobereidheid, waarbij tevens blijkt dat afgestudeerden met een hogere risicobereidheid minder vaak een vaste baan hebben. 
TABEL 4.4 Marginale effecten van verklarende factoren op arbeidsmarktuitkomsten op korte termijn

\begin{tabular}{|c|c|c|c|c|c|}
\hline & Werkzaam & Vaste aanstelling & Baanmatch & Uurloon & Baantevredenheid \\
\hline \multicolumn{6}{|l|}{ Sector } \\
\hline - Economie & Ref. & Ref. & Ref. & Ref. & Ref. \\
\hline - Onderwijs & $0,94 \%$ & $2,32 \%$ & $21,47 \% * * *$ & $-0,49 \%$ & $13,35 \% * * *$ \\
\hline $\begin{array}{l}\text { - Bètatechniek en } \\
\text { Agro \& Food }\end{array}$ & $1,30 \% *$ & $1,30 \%$ & $4,91 \% * * *$ & $2,33 \% * *$ & $8,86 \% * * *$ \\
\hline - Gezondheidszorg & $3,56 \% * * *$ & $19,07 \% * * *$ & $6,61 \% * * *$ & $13,72 \% * * *$ & $20,66 \% * * *$ \\
\hline - Sociale Studies & $1,45 \% *$ & $1,15 \%$ & $-11,83 \% * * *$ & $3,24 \% * *$ & $2,17 \%$ \\
\hline - Kunst & $1,52 \%$ & $12,53 \%$ & $-5,92 \% * *$ & $-23,41 \% * * *$ & $12,63 \%$ \\
\hline $\begin{array}{l}\text { Open voor nieuwe } \\
\text { uitdagingen }\end{array}$ & & $-0,86 \%$ & $2,19 \% *$ & $1,60 \%$ ** & $1,25 \%$ \\
\hline Mate van ambitie & & $2,24 \%$ & $0,26 \%$ & $1,41 \% * *$ & $-2,07 \% *$ \\
\hline Nuttig sociaal netwerk & $0,01 \%$ & $-0,70 \%$ & $0,30 \%$ & $0,09 \%$ & $1,11 \%$ \\
\hline Risicobereidheid & & $-0,02 \%$ & $-0,03 \%$ & $0,27 \%$ & $-0,12 \%$ \\
\hline \multicolumn{6}{|l|}{ Gezinsvorming } \\
\hline Minstens één kind & $2,16 \%$ & $0,05 \%$ & $3,99 \%$ & $-1,05 \%$ & $-2,00 \%$ \\
\hline $\begin{array}{l}\text { Zorg voor kinderen/ } \\
\text { familieleden }\end{array}$ & $0,55 \%$ & $4,20 \%$ & $-1,95 \%$ & $1,91 \%$ & $2,30 \%$ \\
\hline Deeltijd aanstelling & & $-11,65 \% * * *$ & $-7,51 \% * * *$ & $1,46 \%$ & $-9,40 \% * * *$ \\
\hline
\end{tabular}

Noot ${ }^{* * *}=$ Statisch significant bij een alfa van $0,01,{ }^{* *}=$ Statistisch significant bij een alfa van 0,05 *=Statistisch significant bij een alfa van 0,10. Gecontroleerd voor vooropleiding, afstudeercijfer, leeftijd en afstudeercohort.

Om beter zicht te krijgen op de rol van de afzonderlijke verklarende factoren bij het verklaren van effecten van geslacht en migratieachtergrond, zijn alle analyses opnieuw gedraaid, waarbij de verklarende factoren één voor één uit het volledige model zijn weggehaald en er vervolgens weer zijn ingezet. Door de resultaten van het volledige model steeds te vergelijken met de resultaten van het model waarin steeds slechts één van de verklarende factoren ontbreekt, kan een zuiver beeld worden verkregen van de specifieke bijdrage van de betreffende verklarende factor. Wanneer het resterende effect van geslacht of migratieachtergrond veel sterker is bij het ontbreken van een bepaalde verklarende factor dan bij het volledige model, betekent dat dat een relatief groot deel van het effect aan deze verklarende factor kan worden toegeschreven, bij constanthouding van de andere verklarende factoren en controlevariabelen. Wanneer het weglaten van een verklarende factor weinig of niets uitmaakt voor het effect van de betreffende groepskenmerk, betekent dat de betreffende verklarende factor hierin geen rol van betekenis speelt. 
TABEL 4.5 Marginale effecten van verklarende factoren op arbeidsmarktuitkomsten op middellange termijn

\begin{tabular}{|c|c|c|c|c|c|}
\hline & Werkzaam & Vaste aanstelling & Baanmatch & Uurloon & Baantevredenheid \\
\hline Uitkomst korte termijn & $2,41 \% * * *$ & $11,81 \% * * * * * *$ & $20,36 \% * * *$ & $35,44 \% * * *$ & $14,68 \% * * *$ \\
\hline \multicolumn{6}{|l|}{ Sector } \\
\hline - Economie & Ref. & Ref. & Ref. & Ref. & \\
\hline - Onderwijs & $1,22 \% * *$ & $5,50 \% * * *$ & $3,06 \%{ }^{*}$ & $-12,49 \% * * *$ & $2,21 \%$ \\
\hline $\begin{array}{l}\text { - Bètatechniek en Agro } \\
\text { \& Food }\end{array}$ & $0,99 \% *$ & $4,24 \% * * *$ & $-0,67 \%$ & $-0,46 \%$ & $1,04 \%$ \\
\hline • Gezondheidszorg & $0,80 \%$ & $13,53 \% * * *$ & $-0,09 \%$ & $-1,72 \%$ & $5,76 \%$ ** \\
\hline - Sociale Studies & $0,43 \%$ & $3,58 \% * *$ & $-6,05 \% * * *$ & $-8,60 \% * * *$ & $-4,24 \%$ * \\
\hline · Kunst & $0,11 \%$ & $9,05 \%$ & $-2,61 \%$ & $-16,76 \% * * *$ & $-8,68 \%$ \\
\hline $\begin{array}{l}\text { Open voor nieuwe } \\
\text { uitdagingen }\end{array}$ & & $-1,42 \%$ & $1,47 \%$ & $0,51 \%$ & $0,34 \%$ \\
\hline Mate van ambitie & & $-0,09 \%$ & $0,38 \%$ & $3,41 \% * * *$ & $-3,58 \% * * *$ \\
\hline Nuttig sociaal netwerk & $0,23 \%$ & $-0,59 \%$ & $0,96 \% *$ & $0,81 \%$ & $4,18 \% * * *$ \\
\hline Risicobereidheid & & $-1,80 \% * *$ & $1,10 \% *$ & $0,80 \%$ & $2,51 \% * * *$ \\
\hline \multicolumn{6}{|l|}{ Gezinsvorming } \\
\hline - Één kind & $1,50 \%^{* *}$ & $4,42 \% *$ & $2,94 \%$ & $4,25 \%^{* *}$ & $10,16 \%$ *** \\
\hline $\begin{array}{l}\text { - Twee of meer } \\
\text { kinderen }\end{array}$ & $1,98 \% * * *$ & $6,23 \% * *$ & $1,04 \%$ & $4,91 \%^{* * *}$ & $4,37 \%$ \\
\hline \multicolumn{6}{|l|}{$\begin{array}{l}\text { Zorg voor kinderen/ } \\
\text { familieleden }\end{array}$} \\
\hline - Max. éen dag & $-0,82 \%$ & $5,00 \%$ & $-1,21 \%$ & $0,71 \%$ & $-2,33 \%$ \\
\hline - Twee á drie dagen & $-1,82 \% * *$ & $0,39 \%$ & $-2,81 \%$ & $-0,12 \%$ & $-7,40 \% * *$ \\
\hline - Vier dagen of meer & $-2,96 \% * * *$ & $-0,51 \%$ & $-3,38 \%$ & $-1,76 \%$ & $-3,41 \%$ \\
\hline Deeltijd aanstelling & & $-9,59 \%$ *** & $-3,74 \% * * *$ & $-0,43 \%$ & $-6,49 \% * * *$ \\
\hline
\end{tabular}

Noot ${ }^{* * *}=$ Statisch significant bij een alfa van $0,01,{ }^{* *}=$ Statistisch significant bij een alfa van 0,05 *=Statistisch significant bij een alfa van 0,10. Gecontroleerd voor vooropleiding, afstudeercijfer, leeftijd en afstudeercohort.

Tabel 4.6 toont in de tweede kolom het effect van geslacht nadat rekening is gehouden met alle verklarende factoren, en in de kolommen $3 \mathrm{t} / \mathrm{m} 10$ de verandering die optreedt in dit effect als je steeds één van de verklarende factoren weglaat (waarbij we opleidingssector, baanvoorkeuren, gezinsvorming en zorgtaken steeds als een enkele verklarende factor beschouwen). 


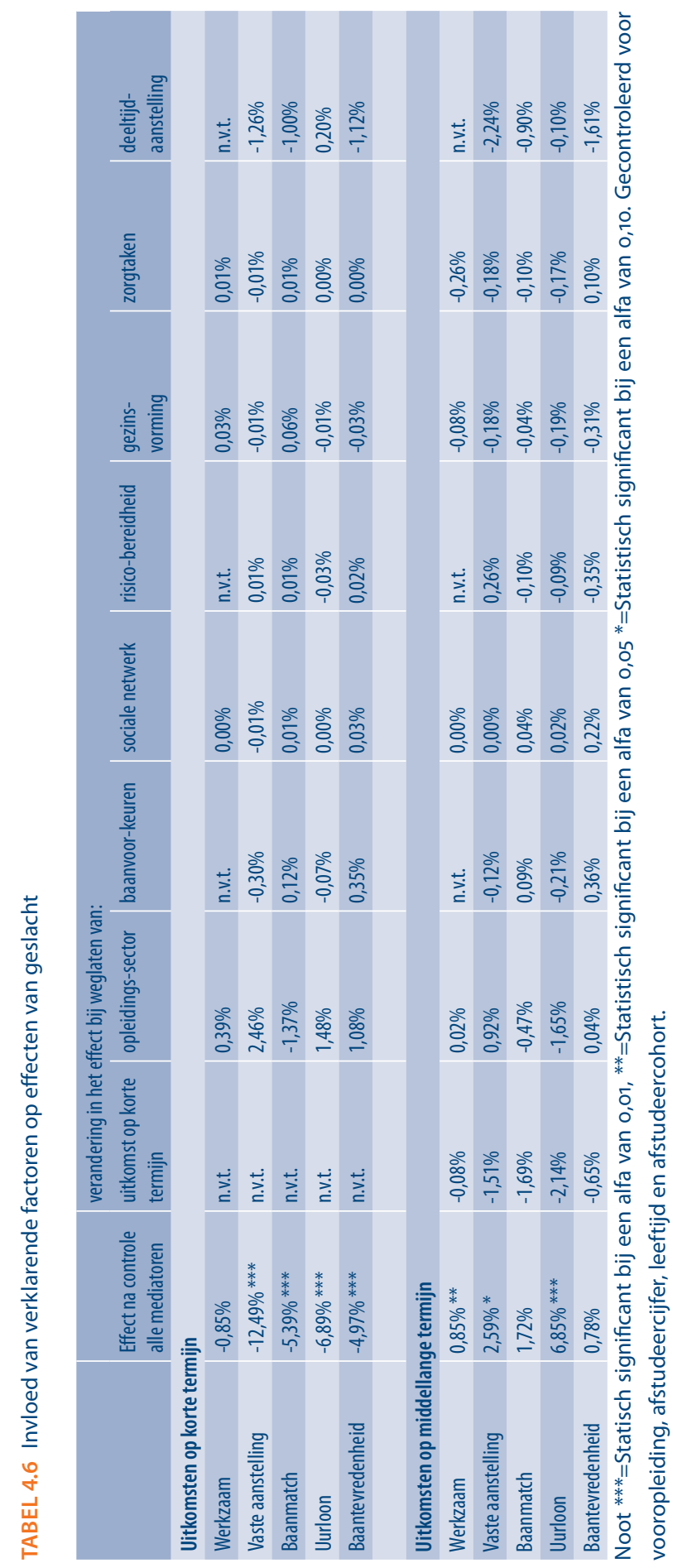


Omdat de meeste effecten van geslacht negatief zijn, verwachten we dat veranderingen die optreden bij weglaten van verklarende factoren doorgaans ook negatief zullen zijn. Uit tabel 4.6 blijkt enigszins verassend dat opleidingssector op de korte termijn het negatieve effect van geslacht op arbeidsmarktuitkomsten in de meeste gevallen juist afzwakt. Met name door hun sterkere voorkeur voor de sector Gezondheidszorg krijgen vrouwen als het ware een "boost" op de arbeidsmarkt op korte termijn, van zo'n 2,5 en 1 procentpunten voor respectievelijk de kans op een vaste aanstellingen en baantevredenheid, evenals een vermindering van hun loonachterstand met ongeveer 1,5\%. Dit betekent feitelijk dat vrouwen het minder goed doen op de arbeidsmarkt dan men op basis van de opleidingssector zou verwachten. Uitzondering op deze regel wordt gevormd door de baanmatch, waar de opleidingssector wel een deel (bijna 1,5 procentpunt) van de verklaring voor de nadelige positie van vrouwen voor zijn rekening neemt. Verder blijkt dat veel van de nadelige positie van vrouwen op de arbeidsmarkt kort na afstuderen toe te schrijven is aan het werken in deeltijd. Deeltijd werk neemt meer dan één procentpunt van het effect van geslacht op vaste aanstellingen, baanmatch en baantevredenheid voor zijn rekening.

Veel van de nadelige positie van vrouwen op de middellange termijn kan worden toegeschreven aan hun slechtere start op de arbeidsmarkt één jaar na afstuderen. Bij de kans op een vaste aanstelling en baanmatch draagt de startpositie op dezelfde indicator voor zo'n 1,5 procentpunt bij aan de nadelige positie van vrouwen, en een slechte start in termen van beloning levert ook $2 \%$ loonnadeel op op de middellange termijn. Ook het werken in deeltijd blijft op de middellange termijn voor vrouwen negatief uitpakken in termen van het hebben van een vast contract (ruim twee procentpunten), baanmatch (bijna één procentpunt) en baantevredenheid (anderhalf procentpunt). Opleidingssector speelt ten slotte ook een rol bij het lage uurloon van vrouwen op middellange termijn (ongeveer 1,5\%), maar zwakt het geslachteffect op de kans op een vaste aanstelling juist af met bijna één procentpunt.

Baanvoorkeuren, sociale netwerken, risicobereidheid, gezinsvorming en zorgtaken spelen hooguit een marginale rol bij de negatieve arbeidsmarktpositie van vrouwen op zowel korte als middellange termijn. Vooral in het geval van gezinsvorming en zorgtaken is dit enigszins verassend. Uit tabel $3.2 \mathrm{kwam}$ immers naar voren dat ongeveer een kwart van de vrouwen vier tot acht jaar na afstuderen tenminste één kind heeft, en dat ze relatief veel zorgtaken hebben vaak voor een aanzienlijk aantal uren. In de literatuur wordt vaak verondersteld dat de nadelige positie van vrouwen op de arbeidsmarkt in sterke mate wordt bepaald door hun grotere verplichtingen in de privésfeer (zie bijvoorbeeld Yavorski et al.,2015). Uit onze analyses blijkt dat echter dit nauwelijks een rol speelt bij de nadelige positie van vrouwelijke hbo'ers in hun vroege carrière.

Uit tabel 4.7 komt tot slot naar voren dat, anders dan bij geslacht, de opleidingssectorkeuze een factor wel een rol van betekenis speelt bij het verklaren van de nadelige positie van afgestudeerden met een niet-westerse migratieachtergrond, vooral op de korte termijn. Een deel van hun nadelige positie in termen van kans op werk (een 
half procentpunt) en baantevredenheid (bijna 2,5 procentpunten) kan hieraan worden toegeschreven. Verder blijken baanvoorkeuren ook een rol te spelen bij hun lagere baantevredenheid op de korte termijn, met bijna een half procentpunt verschil. Op de middellange termijn wordt de lagere kans op werk van niet westerse afgestudeerden in ongeveer gelijke mate bepaald door de opleidingssectorkeuze en de arbeidsmarktsituatie op korte termijn, al blijft er nog een substantieel onverklaard effect over.

Voor afgestudeerden met een westerse migratieachtergrond wordt een substantieel deel van hun nadelige positie in termen van baanmatch op middellange termijn ook bepaald door de opleidingssectorkeuze en de arbeidsmarktsituatie op korte termijn. Hun gunstige positie in termen van uurloon blijkt ook voor een deel aan hun opleidingssectorkeuze te liggen. Opvallend is wel dat ze een hoger uurloon hebben vier tot acht jaar na afstuderen dan wat op basis van hun korte termijn beloning zou worden verwacht. 
旁衰

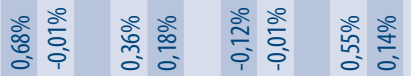

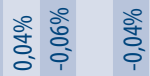

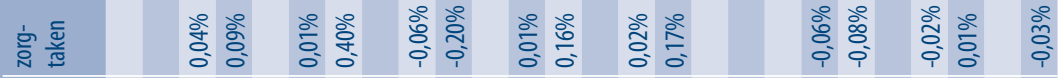

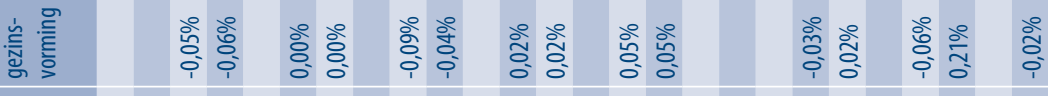

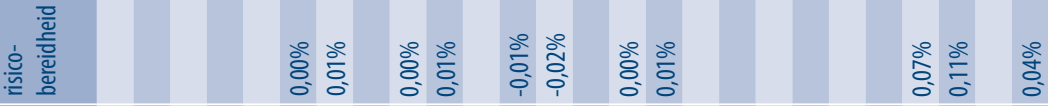

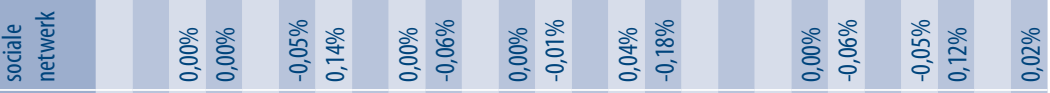

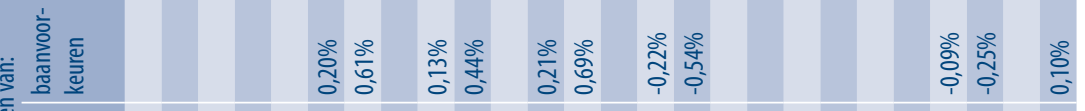

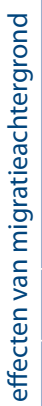

苛

:

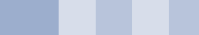

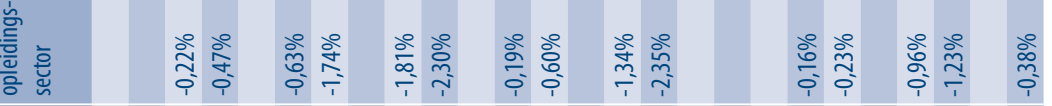

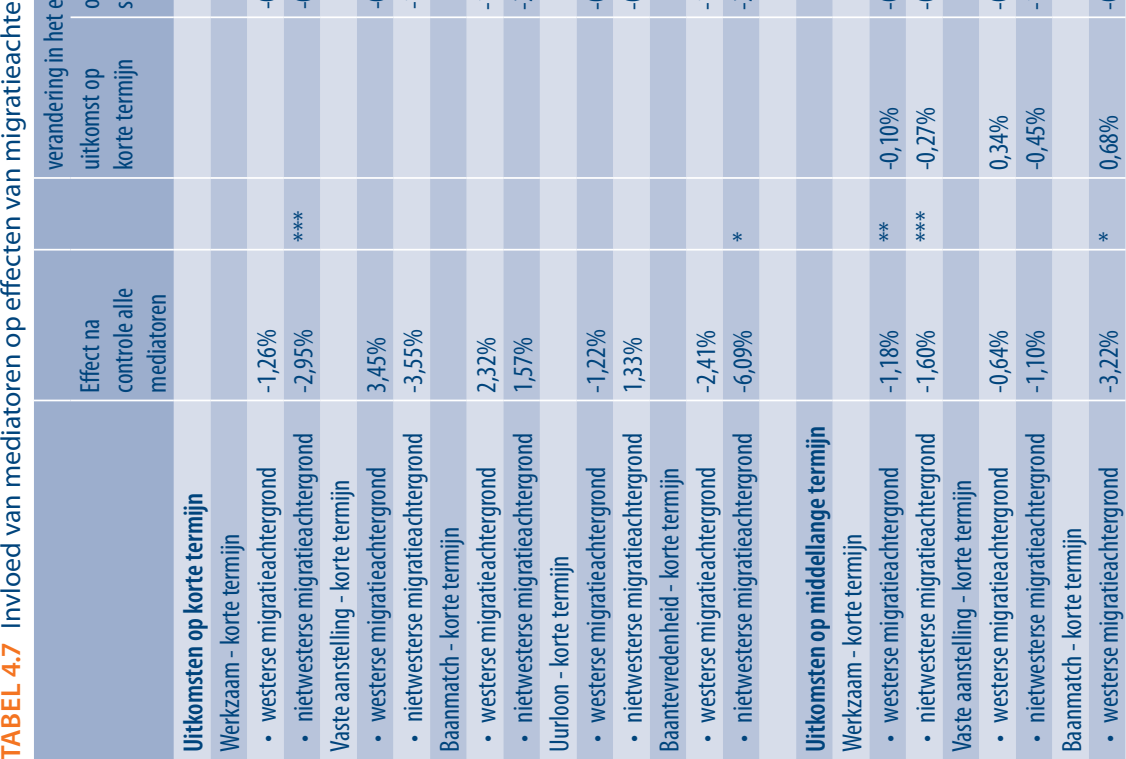




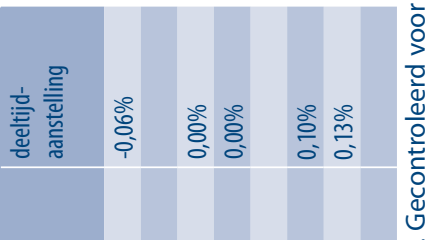

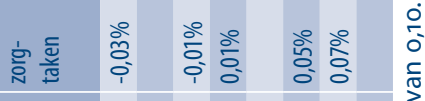

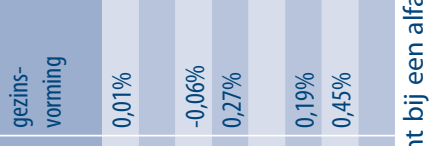

韋

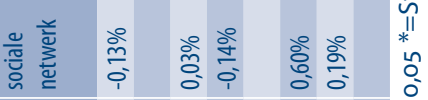

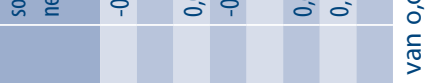

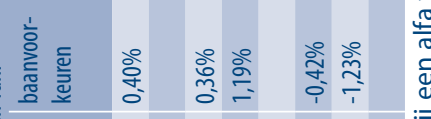

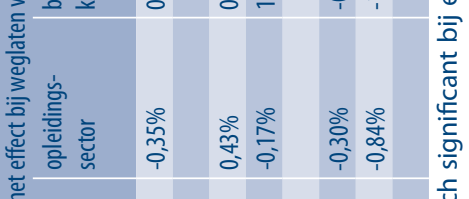

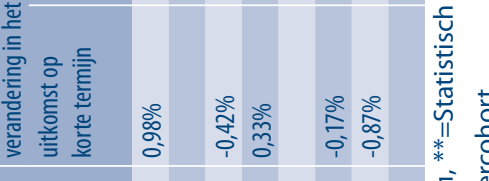

i

它缡

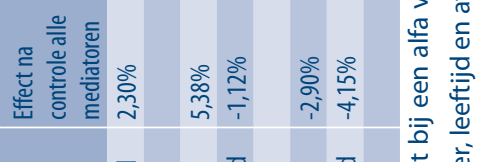

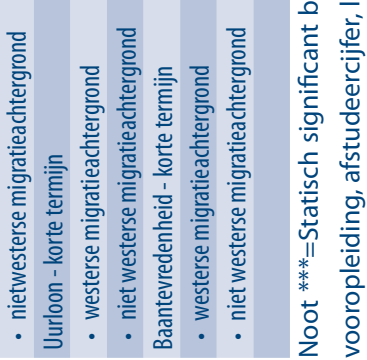





\section{CONCLUSIE EN DISCUSSIE}

Historisch gezien vormen sociale herkomst, geslacht, en migratieachtergrond belangrijke scheidslijnen in het onderwijs en op de arbeidsmarkt. De afgelopen decennia is door de onderwijsexpansie het aantal jongeren uit deze traditioneel achtergestelde groepen in het hoger onderwijs sterk gestegen. In dit rapport hebben we onderzocht hoe de loopbanen van afgestudeerde hbo'ers uit deze groepen heden ten dage verlopen, zowel op korte als middellange termijn. Verlopen deze loopbanen, zoals we op basis van onder andere de moderniseringstheorie mogen verwachten, met relatief weinig problemen, of zijn er nog steeds verschillen in carrièreontwikkeling zichtbaar in vergelijking met afgestudeerde hbo'ers uit traditioneel geprivilegieerde groepen?

Sociale herkomst - het opleidingsniveau van de ouders - blijkt uit onze analyses geen rol van betekenis te spelen bij het bepalen van arbeidsmarktuitkomsten van hbo-afgestudeerden. De enige verschillen die in enige mate significant zijn, laten zelfs een licht nadeel zien voor afgestudeerden met minstens één hoogopgeleide ouder ten opzichte van afgestudeerden met alleen laagopgeleide ouders. Dit betekent niet per se dat sociale herkomst er niet toedoet op de Nederlandse arbeidsmarkt. Uit schoolverlatersdata van mbo-, havo- en vwo-schoolverlaters blijkt immers dat sociale herkomst wel een rol speelt bij de keuze om door te stromen naar vervolgonderwijs, en bij het bepalen van het niveau van de eventuele vervolgstudie (ROA, 2016). Echter, als jongeren eenmaal voor een hbo-opleiding hebben gekozen en deze hebben afgerond, blijken ze zich daarmee effectief te hebben losgemaakt van een eventueel nadeel op de arbeidsmarkt.

Het carrièreverloop van mannen en vrouwen blijkt daarentegen wel fors te verschillen, zowel op korte als op middellange termijn. Vrouwen halen op sommige aspecten een deel van hun achterstand in, zoals bij baantevredenheid en vast contract, terwijl op andere aspecten hun achterstand juist toeneemt, zoals bij uurloon en werkloosheid. Vooral de groeiende beloningskloof - van een $5 \%$ per uur loonnadeel één jaar na afstuderen tot maar liefst een $12 \%$ achterstand vier tot acht jaar na afstuderen - is zorgwekkend. Wanneer we hierbij ook het grote - en in de loop van de carrière groeiende - verschil in gewerkte uren tussen mannen en vrouwen meerekenen, wordt duidelijk dat vrouwelijke hbo'ers op basis van maandbasis veel minder te besteden hebben dan mannen met een vergelijkbare opleiding en vergelijkbare achtergrondkenmerken. 
Uit ons onderzoek blijkt verder dat de nadelige positie van afgestudeerden met een niet-westerse migratieachtergrond vooral in hun structureel veel lagere kans op werk zit, en dat ze in termen van objectieve baankenmerken ongeveer even succesvol zijn als afgestudeerden met een Nederlandse achtergrond. Echter, ondanks het ontbreken van significante verschillen in termen van werkzekerheid, baanmatch en beloning, blijken hbo'ers met een niet-westerse migratieachtergrond iets minder tevreden te zijn met hun werk dan afgestudeerden met een Nederlandse achtergrond. Zowel in termen van de kans op werk als baantevredenheid halen niet-westerse afgestudeerde hbo'ers een deel van hun achterstand in de loop van de tijd in, maar vier tot acht jaar na afstuderen zijn de verschillen weliswaar nog altijd significant.

Een deel van de verschillen naar geslacht en migratieachtergrond bleek toe te schrijven te zijn aan de rol van specifieke verklarende factoren als opleidingssector en baanvoorkeuren. Zo bleek dat een behoorlijk deel van de nadelige positie van vrouwen op de arbeidsmarkt kort na afstuderen toegeschreven kan worden aan het werken in deeltijd. Deeltijd werk neemt meer dan één procentpunt van het effect van geslacht op vaste aanstellingen, baanmatch en baantevredenheid voor zijn rekening. Hoewel er geen effect op uurloon te zien was, is duidelijk dat minder gewerkte uren doorgaans ook een minder riante maandloon betekenen. Deze resultaten onderstrepen het feit dat de deeltijdstatus van veel vrouwelijke hbo'ers met een fors prijskaartje gepaard gaat.

Uit de analyses komt verder naar voren dat de opleidingssectorkeuze een belangrijk factor is bij het bepalen van de nadelige arbeidsmarktpositie van afgestudeerden met een niet-westerse migratieachtergrond, vooral op de korte termijn. Een belangrijk deel van hun nadelige positie in termen van kans op werk en baantevredenheid kan hieraan worden toegeschreven. Verder blijken baanvoorkeuren ook een rol te spelen bij hun lagere baantevredenheid op de korte termijn. Op de middellange termijn is de lagere kans op werk van niet-westerse afgestudeerden ook medebepaald door hun lagere kans op werk op korte termijn, al blijft er nog een substantieel onverklaard effect over.

Enigszins tegen de verwachtingen in bleken gezinsvorming en zorgtaken hooguit een marginale rol te spelen bij de slechtere arbeidsmarktpositie van vrouwen op zowel korte als middellange termijn. Hoewel veel vrouwelijke hbo'ers vier tot acht jaar na afstuderen al kinderen hebben en veel meer tijd aan zorgtaken besteden dan mannelijke hbo'ers, vonden we nauwelijks steun voor de verwachting dat dit een belangrijke barrière vormt voor hun carrièreontwikkeling.

Concluderend blijkt uit onderzoek dat hoewel we in Nederland in de afgelopen decennia heel ver zijn gekomen in het bereiken van gelijke arbeidsmarktkansen voor afgestudeerde hbo'ers van hoge en lage sociale komaf, er nog heel wat stappen zijn te verzetten in het bereiken van gelijke arbeidsmarktuitkomsten voor mannen en vrouwen, en afgestudeerden met en zonder migratieachtergrond. De verklarende analyses die in het kader hiervan in dit onderzoek zijn uitgevoerd bieden alvast aanknopingspunten voor beleidsmakers, werkgevers en studievoorlichters om hier verandering in aan te brengen. 
Met betrekking tot de arbeidsongelijkheid tussen mannen en vrouwen, zien we dat een groot deel van de genderverschillen worden verklaard door de arbeidsmarktsituatie één jaar na afstuderen, het verrichten van deeltijdwerk (alleen bij werkenden) en opleidingssector. Een belangrijke vraag is hoe de resterende genderverschillen in arbeidsmarktontwikkelingen kunnen worden verklaard. Met name op het gebied van ontwikkeling in uurloon en het hebben van een baan blijft nog een beduidend deel van de variantie in ons model onverklaard. Dit zou mogelijk kunnen komen door andere verschillen tussen mannen en vrouwen in arbeidsmarktgedrag zoals onderhandelingsvaardigheden, presentatie skills en overtuigingskracht. Maar het valt ook zeker niet uit te sluiten dat dit resterende verklarende deel is te wijten aan discriminatie door de werkgever. Vervolgonderzoek is nodig om hier uitsluitsel over te geven. Echter, zowel beleidsmakers als werkgevers dienen zich bewust te zijn van de biologische, psychologische en gedragsverschillen tussen mannen en vrouwen en ervoor te zorgen dat deze verschillen zich niet vertalen in minder gunstigste arbeidsmarktvoorwaarden van vrouwen. Met betrekking tot de arbeidsmarktverschillen tussen afgestudeerde hbo'ers met en zonder migratie achtergrond zijn tot slot grote stappen te zetten voor schooldecanen, mentoren en andere studieadviseurs in voortgezet onderwijs door met name leerlingen met een migratieachtergrond goed voor te lichten over de actuele arbeidsmarktperspectieven die met verschillende opleidingskeuzes gepaard gaan. 



\section{LITERATUUR}

Allen, J., Belfi, B., \& Mommers, A. (2016). Van starter tot gevorderde: De loopbaanontwikkeling van hbo'ers in de eerste vijf jaren na afstuderen. Maastricht: ROA.

Anusic, I., \& Schimmack, U. (2016). Stability and change of personality traits, self-esteem, and well-being: Introducing the meta-analytic stability and change model of retest correlations. Journal of Personality and Social Psychology, 110(5), 766.

Argentin, G., \& Triventi, M. (2011). Social inequality in higher education and labour market in a period of institutional reforms: Italy, 1992-2007. Higher education, 61(3), 309-323.

Baert, S., Cockx, B., \& Verhaest, D. (2013). Overeducation at the start of the career: stepping stone or trap?. Labour Economics, 25, 123-140.

Bakens, J., Fouarge, D., \& Peeters, T. (2018). Labour market forecasts by education and occupation up to 2022. ROA: Maastricht.

Ballarino, G., \& Bernardi, F. (2016). The intergenerational transmission of inequality and education in fourteen countries: a comparison. Education, Occupation and Social Origin: A Comparative Analysis of the Transmission of Socio-Economic Inequalities. Cheltenham: Elgar, 255-279.

Barone, C. (2011). Some things never change: Gender segregation in higher education across eight nations and three decades. Sociology of Education, 84(2), 157-176.

Becker, G.S. Human capital. Second edition. New York: Columbia University Press, [1964] 1975.

Bell, D. N., \& Blanchflower, D. G. (2011). Youth unemployment in Europe and the United States. Nordic Economic Policy Review, 1(2011), 11-37.

Berg van den, M. N., de Boom, J., \& Hofman, W. H. A. (2001). Studeren in het wetenschappelijk onderwijs. Trends in de tweede helft van de jaren negentig.

Berggren, C. (2008). Horizontal and vertical differentiation within higher education-gender and class perspectives. Higher Education Quarterly, 62(1-2), 20-39.

Blau, P. M. en Duncan, O.D. (1967). The American Occupational Structure. New York: John Wiley.

Borghans, L., \& Groot, L. (1999). Educational presorting and occupational segregation. Labour Economics, 6(3), 375-395.

Bourdieu, P. (1986). The forms of capital. In Richardson, J. G. (Ed.), Handbook for Theory and Research for the Sociology of Education. New York: Greenwood Press, pp. 241-258.

Boxman, E., \& Flap, H. (2017). Getting started: the influence of social capital on the start of the occupational career. In Social capital (pp. 159-181). Routledge.

Bradley, S., \& Nguyen, A. N. (2004). 13 The school-to-work transition. International handbook on the economics of education, 484.

Büchel, F., \& Mertens, A. (2004). Overeducation, undereducation, and the theory of career mobility. Applied economics, 36(8), 803-816. 
Card, D., Cardoso, A. R., Heining, J., \& Kline, P. (2018). Firms and labor market inequality: Evidence and some theory. Journal of Labor Economics, 36(S1), S13-S70.

Caspi, A., Wright, B. R. E., Moffitt, T. E., \& Silva, P. A. (1998). Early failure in the labor market: Childhood and adolescent predictors of unemployment in the transition to adulthood. American sociological review, 63, 424-451.

CBS (2016a). Gelijk loon voor gelijk werk? Banen en lonen bij de overheid en bedrijfsleven, Den Haag: CBS.

CBS (2016b). Jaarrapport Integratie 2016, Den Haag: CBS.

CBS (2018). Hoger onderwijs; eerstejaarsstudenten, onderwijssoort en opleidingsfase. Geraadpleegd via www.statline.cbs.nl/Statweb/publication/?VW=T\&DM=SLNL\&PA=835 $39 \mathrm{NED} \& \mathrm{D} 1=0 \& \mathrm{D}_{2}=\mathrm{a} \& \mathrm{D}_{3}=0 \& \mathrm{D}_{4}=\mathrm{a} \& \mathrm{D} 5=0 \& \mathrm{D} 6=1 \& \mathrm{D} 7=\mathrm{a} \& \mathrm{HD}=180822-1252 \& \mathrm{HDR}=\mathrm{T}, \mathrm{G} 2, \mathrm{G} 3, \mathrm{G}$ $5, \mathrm{G} 1 \& \mathrm{STB}=\mathrm{G} 4, \mathrm{G} 6$

Charles, K. K., \& Hurst, E. (2003). The correlation of wealth across generations. Journal of political Economy, 111(6), 1155-1182.

Coleman, J. S. (1988). Social capital in the creation of human capital. The American Journal of Sociology, 94, 95-120.

Croson, R., \& Gneezy, U. (2009). Gender differences in preferences. Journal of Economic literature, $47(2), 448-74$.

Dohmen, T., Falk, A., Huffman, D., \& Sunde, U. (2011). The intergenerational transmission of risk and trust attitudes. The Review of Economic Studies, 79(2), 645-677.

Dumais, S. A. (2002). Cultural capital, gender, and school success: The role of habitus. Sociology of education, 44-68.

Duru-Bellat, M., Kieffer, A., \& Reimer, D. (2008). Patterns of social inequalities in access to higher education in France and Germany. International journal of comparative sociology, 49(4-5), 347-368.

Eccles, J. (2011). Gendered educational and occupational choices: Applying the Eccles et al. model of achievement-related choices. International Journal of Behavioral Development, 35(3), 195-201.

Eccles, J. (2011). Gendered educational and occupational choices: Applying the Eccles et al. model of achievement-related choices. International Journal of Behavioral Development, 35(3), 195-201.

Elfering, S., Kuijk, J. van \& Mommers, A, (2014), Kansen voor allochtone BBL'ers, ITS, Radboud Universiteit Nijmegen.

Eriksson, S., \& Rooth, D. O. (2014). Do employers use unemployment as a sorting criterion when hiring? Evidence from a field experiment. American Economic Review, 104(3), 1014-39.

Evans, C. D., \& Diekman, A. B. (2009). On motivated role selection: Gender beliefs, distant goals, and career interest. Psychology of Women Quarterly, 33(2), 235-249.

Ferreira, M., Künn-Nelen, \& A, de Grip, A (2017). Work-Related Learning and Skill Development in Europe: Does Initial Skill Mismatch Matter? in Polachek, S.W., Pouliakas, K., Russo, G. \& Tatsiramos, K. (ed.) Skill Mismatch in Labor Markets (Research in Labor Economics, Volume 45) Emerald Publishing Limited, pp.345 - 407, First published: 28 April 2015

Flory, J. A., Leibbrandt, A., \& List, J. A. (2010). Do competitive work places deter female workers? A large-scale natural field experiment on gender differences in job-entry decisions (No. W16546). National Bureau of Economic Research. 
Fortin, N. M. (2005). Gender role attitudes and the labour-market outcomes of women across OECD countries. Oxford review of Economic Policy, 21(3), 416-438.

Gartell, M. (2009). Unemployment and subsequent earnings for Swedish college graduates: A study of scarring effects (No. 2009: 10). Working paper//IFAU-Institute for Labour Market Policy Evaluation.

Gent, M.J. van, Hello, E., Odé, A.W.M., Tromp, E., Stouten, J. (2006). Hogeropgeleide allochtonen op weg naar werk: successen en belemmeringen, Amsterdam: Regioplan.

Giesecke, J., Schindler, S. (2008). Field of study and flexible work: a comparison between Germany and the UK. International Journal of Comparative Sociology, 49(4-5), 283-304.

Griffith, A. R. (1980). Justification for a Black career development. Counselor Education and Supervision, 19(4), 301-309.

Grip, A. de, Bosma, H., Willems, D., \& Van Boxtel, M. (2008). Job-worker mismatch and cognitive decline. Oxford Economic Papers, 60(2), 237-253.

Halek, M., \& Eisenhauer, J. G. (2001). Demography of risk aversion. Journal of Risk and Insurance, 1-24.

Hirschi, A. (2010). Positive adolescent career development: The role of intrinsic and extrinsic work values. The career development quarterly, 58(3), 276-287.

Hjort, P., Holvikivi, J., Vesikivi, P., \& Lukkarinen, S. (2015). Student collaboration and independence from day one in higher education. In the Proceedings of 43rd Annual SEFI Conference, Orléans, France.

Van Hooft, E. A., Born, M. P., Taris, T. W., \& Van der Flier, H. (2006). Ethnic and gender differences in applicants' decision-making processes: An application of the theory of reasoned action. International Journal of Selection and Assessment, 14(2), 156-166.

van Houten, J., Gesthuizen, M., \& Wolbers, M. H. (2012). Statusverwerving en de rol van verenigingslidmaatschap als nieuwe compenserende strategie. Mens en maatschappij, 87(2), 125-149.

Hryshko, D., Luengo-Prado, M. J., \& Sørensen, B. E. (2011). Childhood determinants of risk aversion: The long shadow of compulsory education. Quantitative Economics, 2(1), 37-72.

Jackson, M., Luijkx, R., Pollak, R., Vallet, L. A., \& van de Werfhorst, H. G. (2008). Educational fields of study and the intergenerational mobility process in comparative perspective. International Journal of Comparative Sociology, 49(4-5), 369-388.

Jacob, M., Klein, M., en lannelli, C. (2015). The impact of social origin on graduates' early occupational destinations - An Anglo-German comparison. European Sociological Review, 31(4), 460-476.

Jennissen, R. P. W., \& Oudhof, J. (2007). Ontwikkelingen in de maatschappelijke participatie van allochtonen. Boom Juridische uitgevers.

Johnson, M. K., \& Mortimer, J.T. (2011). Origins and outcomes of judgments about work. Social Forces, 89(4), 1239-1260.

Johnson, M. K. (2002). Social origins, adolescent experiences, and work value trajectories during the transition to adulthood. Social forces, 80(4), 1307-1340.

Kalter, F. \& Kogan, I. (2002). Ethnic Inequalities at Labour Market Entry in Belgium and Spain (Working Paper no 49). Retrieved from Mannheimer Zentrum für Europäische Sozialforschung website: http://www.mzes.uni-mannheim.de/publications/wp/wp-49. pdf 
Kanas, A., Van Tubergen, F., \& Van der Lippe, T. (2011). The role of social contacts in the employment status of immigrants: A panel study of immigrants in Germany. International Sociology, 26(1), 95-122.

Koning, J. D., Gelderblom, A., \& Gravesteijn, J. (2010). Techniek: Exact goed? Het keuzeproces van allochtone en autochtone leerlingen in het $(v)$ mbo verklaard.

Konrad, A. M., Ritchie Jr, J. E., Lieb, P., \& Corrigall, E. (2000). Sex differences and similarities in job attribute preferences: a meta-analysis. Psychological bulletin, 126(4), 593.

Kraaykamp, G., Tolsma, J., \& Wolbers, M. H. (2013). Educational expansion and field of study: trends in the intergenerational transmission of educational inequality in the Netherlands. British Journal of Sociology of Education, 34(5-6), 888-906.

Kroft, K., Lange, F., \& Notowidigdo, M. J. (2013). Duration dependence and labor market conditions: Evidence from a field experiment. The Quarterly Journal of Economics, 128(3), 11231167.

Lancee, B. (2012). The economic returns of bonding and bridging social capital for immigrant men in Germany. Ethnic and Racial Studies, 35(4), 664-683.

Lin, N., 1999. Building a network theory of social capital. Connections 22, $28-51$.

Lin, N. (2000). Inequality in social capital. Contemporary sociology, 29(6), 785-795.

Lin, N., Ensel, W. M., \& Vaughn, J. C. (1981). Social resources and strength of ties: Structural factors in occupational status attainment. American sociological review, 393-405.

Lindsay, P., \& Knox, W. E. (1984). Continuity and change in work values among young adults: A longitudinal study. American Journal of Sociology, 89(4), 918-931.

Lucas, S. R. (2001). Effectively maintained inequality: Education transitions, track mobility, and social background effects. American journal of sociology, 106(6), 1642-1690.

Luzzo, D. A., \& McWhirter, E. H. (2001). Sex and ethnic differences in the perception of educational and career-related barriers and levels of coping efficacy. Journal of Counseling \& Development, 79(1), 61-67.

McCormick, B. (1990). A theory of signalling during job search, employment efficiency, and "stigmatised" jobs. The Review of Economic Studies, 57(2), 299-313.

McPherson en Smith-Lovin 1982

Meng, C., Verhagen, A., Huijgen, T. (2014). Van opleiding naar arbeidsmarkt. In: SCP, Jaarrapport integratie 2013: Participatie van migranten op de arbeidsmarkt (p. 109-144). Den Haag: SCP.

Mora, J. G., Garcia-Aracil, A., en Vila, L. E. (2007). Job satisfaction among young European higher education graduates. Higher Education, 53(1), $29-59$.

Mouw, T. (2002). Racial differences in the effects of job contacts: Conflicting evidence from cross-sectional and longitudinal data. Social Science Research, 31(4), 511-538.

Merens, A., Bucx, F., \& Meng, C. (2017). Eerste treden op de arbeidsmarkt. Den Haag: SCP.

Nordström Skans, O. (2011). Scarring effects of the first labor market experience, Discussion paper series // Forschungsinstitut zur Zukunft der Arbeit, No. 5565, Institute for the Study of Labor (IZA), Bonn.

Ortiz, L., \& Kucel, A. (2008). Do fields of study matter for over-education? The cases of Spain and Germany. International Journal of Comparative Sociology, 49(4-5), 305-327.

Pissarides, C. A. (1974). Risk, job search, and income distribution. Journal of Political Economy, $82(6), 1255-1267$. 
Reimer, D., \& Pollak, R. (2010). Educational expansion and its consequences for vertical and horizontal inequalities in access to higher education in West Germany. European Sociological Review, 26(4), 415-430.

ROA (2016). Schoolverlaters tussen onderwijs en arbeidsmarkt 2015, Maastricht: ROA.

Ruijters, C. (1981). Mag de gehuwde ambtenares blijven? Een verslag van de op- en neergang van een principe. Politieke Opstellen, 1.

Salverda, 2015

Säve-Söderbergh, J. (2007). Are women asking for low wages? gender differences in wage bargaining strategies and ensuing bargaining success.

Scherer, S. (2004). Stepping-stones or traps? The consequences of labour market entry positions on future careers in West Germany, Great Britain and Italy. Work, employment and society, 18(2), 369-394.

SCP/CBS. (2016). Emancipatiemonitor 2016, Den Haag, SCP/CBS.

Seibel, V., \& van Tubergen, F. (2013). Job-search methods among non-western immigrants in the Netherlands. Journal of Immigrant \& Refugee Studies, 11(3), 241-258.

Smyth, E., \& Steinmetz, S. (2008). Field of study and gender segregation in European labour markets. International Journal of Comparative Sociology, 49(4-5), 257-281.

Sören, 2009

Sousa-Poza, A., \& Sousa-Poza, A. A. (2000). Taking another look at the gender/job-satisfaction paradox. Kyklos, 53(2), 135-152.

Stewart, M. B. (2007). The interrelated dynamics of unemployment and low-wage employment. Journal of applied econometrics, 22(3), 511-531.

Tam, T. (1997). Sex segregation and occupational gender inequality in the United States: Devaluation or specialized training?. American Journal of Sociology, 102(6), 1652-1692.

Tolsma, J., \& Wolbers, M. H. (2010). Onderwijs als nieuwe sociale scheidslijn? De gevolgen van onderwijsexpansie voor sociale mobiliteit, de waarde van diploma's en het relatieve belang van opleiding in Nederland. Tijdschrift voor Sociologie 31 (3-4), 239-259.

Tolsma, J., \& Wolbers, M. H. (2016). Social origin and inequality in educational returns in the Dutch labour market. Education, Occupation and Social Origin: A Comparative Analysis of the Transmission of Socio-Economic Inequalities, Cheltenham: Edward Elgar Publishing, 114-131.

Tolsma, J., \& Wolbers, M. H. (2014). Social origin and occupational success at labour market entry in The Netherlands, 1931-80. Acta Sociologica, 57(3), 253-269.

Tolsma, J., Coenders, M., \& Lubbers, M. (2007). Trends in ethnic educational inequalities in the Netherlands: a cohort design. European Sociological Review, 23(3), 325-339.

Triventi, M. (2013a). Stratification in higher education and its relationship with social inequality: A comparative study of 11 European countries. European Sociological Review, 29(3), 489-502.

Triventi, M. (2013b). The role of higher education stratification in the reproduction of social inequality in the labor market. Research in Social Stratification and Mobility, 32, 45-63.

Triventi, M., Vergolini, L., \& Zanini, N. (2017). Do individuals with high social background graduate from more rewarding fields of study? Changing patterns before and after the 'Bologna process'. Research in Social Stratification and Mobility, 51, 28-40. 
Tubergen, F. van (2014) Size and socio-economic resources of core discussion networks in the Netherlands: differences by national-origin group and immigrant generation, Ethnic and Racial Studies, 37:6, 1020-1042, DOI: 10.1080/01419870.2012.734390

Turner, C. B., \& Turner, B. F. (1995). Race and Sex Discrimination in Occupations: A 20-Year Replication.

Verbruggen, M., van Emmerik, H., Van Gils, A., Meng, C., \& de Grip, A. (2015). Does early-career underemployment impact future career success? A path dependency perspective. Journal of Vocational Behavior, 90, 101-110.

Verhoeven, N., Jansen, W., \& Tazelaar, F. (2000). Sociaal kapitaal van mannen en vrouwen op de arbeidsmarkt. Tijdschrift voor Arbeidsvraagstukken, 16(1), 49-67.)

Vila, L. E., Garcia-Aracil, A., \& Mora, J. G. (2007). The distribution of job satisfaction among young european graduates: does the choice of study field matter?. The Journal of Higher Education, 78(1), 97-118.

Van de Werfhorst, H. G. (2002). Fields of study, acquired skills and the wage benefit from a matching job. Acta Sociologica, 45(4), 286-303.

Van de Werfhorst, H. G., \& Luijkx, R. (2010). Educational field of study and social mobility: Disaggregating social origin and education. Sociology, 44(4), 695-715.

Werfhorst, Herman G. van der, Sullivan, Alice and Cheung, Sin Yi(2003) 'Social Class, Ability and Choice of Subject in Secondary and Tertiary Education in Britain', British Educational Research Journal, 29, 41- 62

Werfhorst, H. G. van der, De Graaf, N. D., \& Kraaykamp, G. (2001). Intergenerational resemblance in field of study in the Netherlands. European Sociological Review, 17(3), 275-293.

Yavorsky, J. E., Kamp Dush, C. M., \& Schoppe-Sullivan, S. J. (2015). The production of inequality: The gender division of labor across the transition to parenthood. Journal of Marriage and Family, 77(3), 662-679. 


\section{BIJLAGE A: GEBRUIKTE SCHALEN VOOR NIEUWE UITDAGINGEN, MATERIËLE AMBITIE EN SOCIAAL NETWERK}

\begin{tabular}{|c|c|c|c|}
\hline Schaalnaam & Gebruikte items & Antwoordschaal & Cronb. a \\
\hline $\begin{array}{l}\text { Nieuwe } \\
\text { uitdagingen }\end{array}$ & $\begin{array}{l}\text { Geef aan hoe belangrijk onderstaande } \\
\text { baankenmerken voor u zijn: } \\
\text { - Mogelijkheid om nieuwe dingen te } \\
\text { leren } \\
\text { - Nieuwe uitdagingen } \\
\text { In hoeverre [is de volgende stelling] op u } \\
\text { van toepassing? } \\
\text { Ik houd er van nieuwe dingen te zien en } \\
\text { mee te maken }\end{array}$ & 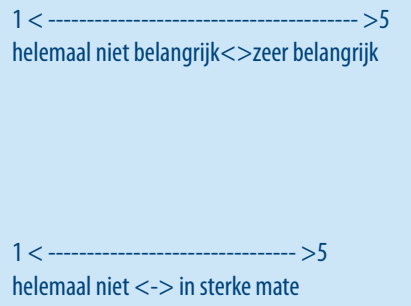 & 0,70 \\
\hline Materiële ambitie & $\begin{array}{l}\text { Geef aan hoe belangrijk onderstaande } \\
\text { baankenmerken voor u zijn: } \\
\text { - - Sociale status } \\
\text { - - Hoog inkomen } \\
\text { - - Goede carrièreperspectieven }\end{array}$ & $\begin{array}{l}1<--1- \\
\text { helemaal niet belangrijk<> zeer belangrijk }\end{array}$ & 0,61 \\
\hline Sociaal netwerk & $\begin{array}{l}\text { Hoe nuttig denkt u dat uw eigen sociale } \\
\text { netwerk (vrienden, familie, collega's, } \\
\text { voormalige docenten enz.) zou zijn), } \\
\text { wanneer u } \\
\text { - informatie nodig zou hebben over } \\
\text { mogelijk (nieuw) werk? } \\
\text { - hulp nodig zou hebben bij het direct } \\
\text { verkrijgen van (nieuw) werk? } \\
\text { - hulp nodig zou hebben bij het } \\
\text { opzetten van een eigen bedrijf? }\end{array}$ & $\begin{array}{l}1<---1------>5 \\
\text { niet zo nuttig }<->\text { zeer nuttig }\end{array}$ & 0,79 \\
\hline
\end{tabular}


